\title{
Colored Speech: Cross Burnings, Epistemics, and the Triumph of the Crits?
}

\author{
Guy-URIEl E. Charles*
}

\section{INTRODUCTION}

Virginia v. Black ${ }^{1}$ represents a complete reversal in the Court's approach to the constitutionality of anti-cross-burning statutes. In R.A.V. v. City of St. Paul, ${ }^{2}$ a unanimous Supreme Court held that St. Paul's ordinance regulating cross burnings violated the First Amendment. ${ }^{3}$ Writing for the Court, Justice Scalia explained that the purpose of the ordinance was not to target the supposed harm caused by cross burnings, conduct which he characterized as "obnoxious" and even "reprehensible," but to suppress the politically unpopular message of white supremacy. ${ }^{5}$ For Justice Scalia and the R.A.V. majority, the ordinance represented an exercise in political correctness that was incompatible with the First Amendment. ${ }^{6}$

In Virginia v. Black, slightly more than a decade later and in striking departure from R.A.V., a divided Supreme Court upheld a Virginia statute that singled out cross burnings for regulation. Justice O'Connor's opinion for the Court in Black displayed a sensitivity to the harm caused by cross burning that

* Russell M. and Elizabeth M. Bennett Professor of Law, University of Minnesota Law School; Senior Fellow for Law and Politics, Institute on Race and Poverty; Faculty Affiliate, Center for the Study of Political Psychology. I have been pushed by everyone who read this paper to think more deeply about the issues that it raises. Their insights have undeniably improved the paper's contents. For this reason, I am extremely grateful to Michelle Adams, Larry Alexander, Jeannine Bell, Brian Bix, Jim Chen, Dan Farber, Mary Lou Fellows, Kim Forde-Mazrui, Luis Fuentes-Rohwer, Nicole Garnett, Heidi Kitrosser, Caleb Mason, David McGowan, Miranda McGowan, Angela Onwuachi-Willig, Michael Stokes Paulsen, Gregg Polsky, Fred Schauer, Shayna Sigman, Cass Sunstein, and Mark Tushnet for discussions and comments on this Article. I presented this piece at the University of Indiana Law School, Bloomington Faculty Workshop. I would like to thank the workshop participants, in particular Daniel Conkle, Charles Geyh, Ajay Mehrotra, and Susan Williams. I am deeply thankful to the wondrous librarians at the University of Minnesota Law Library. Michael Casper, Jared Hager, Pamela J. Jensen, Michelle Lo, and Elizabeth Radosevich provided wonderful suggestions and research assistance.

1. 538 U.S. 343 (2003).

2. 505 U.S. 377 (1992).

3. Justice Scalia wrote the opinion of the Court and was joined by Chief Justice Rehnquist and Justices Kennedy, Souter, and Thomas. Justice White wrote an opinion concurring in the judgment that was joined by Justices Blackmun and O'Connor in its entirety, and by Justice Stevens except as to Part I.A. Justice Blackmun filed a separate opinion concurring in the judgment. Justice Stevens also filed a separate opinion concurring in the judgment, Part 1 of which was joined by Justices White and Blackmun.

4. R.A.V., 505 U.S. at $393,396$.

5. Id. at 392 .

6. See Jeremy J. Ofseyer, Speech or Opinion? Two Objects of First Amendment Immunity, 2002 UTAH L. REV. 843, 921-22 ("[I]n R.A.V., the Court seemed to fear that the lightning rod issue of hate speech had resulted in local bans, which misused the traditional fighting words doctrine to enforce prevailing standards of political correctness."). 
is conspicuously absent in Justice Scalia's opinion in R.A.V. Justice O'Connor devoted an entire section of her opinion to reviewing the historical meaning of cross burnings in the United States. ${ }^{8}$ She summed up this historical review by remarking that "while a burning cross does not inevitably convey a message of intimidation, often the cross burner intends that the recipients of the message fear for their lives. And when a cross burning is used to intimidate, few if any messages are more powerful." 9

As a consequence of the Black Court's newfound historical understanding of the social meaning of cross burnings, its doctrinal posture vis-à-vis crossburning statutes differs dramatically from that of the Court in R.A.V. In Black, Justice O'Connor explained that in light of the historical meaning of cross burning, the practice can be proscribed in a manner consistent with the First Amendment. ${ }^{10}$ This doctrinal characterization of cross burning cannot be squared with Justice Scalia's opinion in R.A.V. In R.A.V., Justice Scalia's view of the putative harm caused by cross burning led him to conclude, "St. Paul has sufficient means at its disposal to prevent [cross burnings] without adding the First Amendment to the fire."11 Thus, while the majority in R.A.V. indulged in the obligatory acknowledgment that cross burnings cause some harm, its grudging acknowledgment did not affect its doctrinal analysis.

Remarkably, though the Black Court purported to follow R.A.V., it seemed to have accepted wholesale, at least implicitly, a central premise of statutes prohibiting cross burning: that cross burning is more pernicious than other types of speech-related harms and hence that statutes banning the practice deserve greater solicitude under the First Amendment. ${ }^{12}$ This is a proposition that a majority of the Court found insupportable and rejected completely in R.A.V. ${ }^{13}$ Thus, following R.A.V., one could have reasonably concluded that statutes prohibiting cross burnings, even if narrowly tailored, are unconstitutional. ${ }^{14}$ In comparison, the various opinions in Black support the conclusion that none of

7. See infra text accompanying notes 376-378.

8. Black, 538 U.S. at $352-57$.

9. Id. at 357 .

10. Id. at $359-60$.

11. R.A.V., 505 U.S. at 396; see also id. at 392.

12. See Akhil Reed Amar, The Case of the Missing Amendments: R.A.V. v. City of St. Paul, 106 HARv. L. REV. 124, 125-26 (1992).

13. See id.

14. See R.A.V., 505 U.S. at 402 (White, J., concurring) (noting that the majority's approach "necessarily signals that expressions of violence, such as the message of intimidation and racial hatred conveyed by burning a cross on someone's lawn, are of sufficient value to outweigh the social interest in order and morality that has traditionally placed such fighting words outside the First Amendment"); see also id. at 403-04 ("Under the majority's view, a narrowly drawn, content-based ordinance could never pass constitutional muster if the object of that legislation could be accomplished by banning a wider category of speech.").

In the wake of R.A.V, many state courts struck down statutes prohibiting cross burning as inconsistent with the First Amendment. See, e.g., State v. Sheldon, 629 A.2d 753 (Md. 1993); State v. Vawter, 642 A.2d 349 (N.J. 1994); State v. Ramsey, 430 S.E.2d 511 (S.C. 1993); State v. Talley, 858 P.2d 217 (Wash. 1993). 
the current Justices would strike down a narrowly drawn cross-burning statute. $^{15}$

Furthermore, while the opponents of cross-burning statutes in R.A.V. were, as expected, the most conservative Justices on the Court-including Chief Justice Rehnquist and Justices Scalia, Kennedy, and Thomas-such is not the case in Black. In Black, all of the Court's recognized conservatives, with the exception of Justice Kennedy, indicate a willingness to uphold a narrowly drawn crossburning statute. In fact, of the Justices who were in the majority in $R . A . V$., all of whom are on the current Court, only Justices Kennedy and Souter come close to maintaining the same analytical posture toward cross-burning statutes in Black as they did in R.A.V. Thus, a majority of the Court's conservatives have adopted the position on hate speech typically identified with liberals. ${ }^{16}$

Most notably, and in a delectable and ironic twist, in Black, the Court's conservatives essentially accepted the intellectual framework and the mode of analysis suggested previously by the critical race theorists. ${ }^{17}$ Indeed, the Justice in Black whose view most closely resembles that of the critical race theorists is none other than Justice Thomas. ${ }^{18}$ This is' a posture against which the Court's conservatives reacted vigorously in $R . A . V^{19}$

The Court's opinion in Black thus raises a number of extremely interesting questions. First, what accounts for the Court's decision to retreat from R.A.V.'s absolutist approach? Relatedly, what prompted Justice Scalia, who authored the Court's opinion in R.A.V., and Chief Justice Rehnquist, who signed on to that opinion, apparently to change their minds in Black? In this Article I highlight the crucial role that Justice Thomas played in Black and demonstrate how his perspective is critical to the outcome of the case. I rely upon the concept of epistemic authority to explain Justice Thomas's influence in Black $^{20}$ and argue that Justice Thomas understood the harm caused by cross burnings from his unique vantage point as the only African-American Justice on the Court. As a consequence, Justice Thomas commanded the epistemic deference of his colleagues.

Second, Black provides us with an opportunity to revisit R.A.V. and to reexamine its meaning both prior to the Court's decision in Black and now in

15. Note that Justice Souter's dissent does not appear to disagree with the majority's core conclusion that cross-burning statutes are not facially invalid. Justice Souter regards this conclusion as a "more flexible" and "pragmatic" modification of R.A.V. Black, 538 U.S. at 382, (Souter, J., concurring in part and dissenting in part). While purporting to "reserve judgment on that doctrinal development," Justice Souter does not maintain that it is a doctrinal development that he finds unfavorable. Id.

16. Kathleen M. Sullivan, The Justices of Rules and Standards, 106 HaRv. L. Rev. 22, 103-04 (1992).

17. 'See infra text accompanying notes 367-395.

18. See infra text accompanying notes $367-395$.

19. See R.A.V., 505 U.S. at 392-94; Cedric Merlin Powell, The Mythological Marketplace of Ideas: R.A.V., Mitchell, and Beyond, 12 Harv. BlackLetTer L.J. 1, 18-20 (1995).

20. Epistemic authority is authority based upon superior knowledge. I explain the concept and its application to the case infra text accompanying notes 261-272. 
light of Black. Undoubtedly, Black has modified R.A.V., which was once thought to be an important and permanent fixture in the Court's First Amendment firmament. $^{21}$

Third, while the Court presumed that its decision in Black is consistent with R.A.V., in view of the Court's analysis in Black one must question whether the two decisions are reconcilable. One cannot reconcile these cases on the ground that the ordinance in R.A.V. is different from the Virginia statute in Black because Virginia's cross-burning statute in Black is in material respects similar to St. Paul's ordinance in $R . A . V^{22}$ In fact, one can apply equally Justice Scalia's reasoning in R.A.V. to strike down the Virginia statute at issue in Black or Justice O'Connor's reasoning in Black to uphold St. Paul's ordinance in R.A.V. ${ }^{23}$ Further, these cases cannot be explained on the ground that the First Amendment landscape has changed such that the Court possesses new doctrinal tools for understanding the relationship between cross burning and the First Amendment in Black that did not exist in R.A.V.

Part I of this Article examines the Court's decision in Black. Part II reviews the Court's decision in R.A.V. Part III explores the meaning of R.A.V. Part IV demonstrates the role that Justice Thomas played in bringing about the result in Black. Part IV also explains how Black represents at least a partial triumph for critical race theorists and the doctrinal approach to regulating cross burning that they have advocated. Part V maintains that Black cannot be squared with R.A.V.

\section{BLACK}

\section{A. THE FACTS}

On August 22, 1998, Barry Black planned and led a Ku Klux Klan rally in Carroll County, Virginia. ${ }^{24}$ The rally was held on private property, with the owner's permission, near a state highway. ${ }^{25}$ Approximately thirty people attended the gathering, at which the expected paeans to white supremacist ideals

21. See, e.g., Edward J. Cleary, Beyond the Burning Cross: The First Amendment and the LANDMARK R.A.V. CASE (1994); Alan E. Brownstein, Interpreting the Religion Clauses in Terms of Liberty, Equality, and Free Speech Values-A Critical Analysis of "Neutrality Theory" and Charitable Choice, 13 Notre Dame J.L. Ethics \& Pub. Pol'y 243, 269 n.54 (1999) (referring to R.A.V. as an "important" First Amendment case); Steven J. Heyman, Spheres of Autonomy: Reforming the Content Neutrality Doctrine in First Amendment Jurisprudence, 10 WM. \& MARY BILL RTs. J. 647, 650 (2002) (listing R.A.V. among "important" recent decisions); Claire L'Heureux-Dubé, The Importance of Dialogue: Globalization and the International Impact of the Rehnquist Court, 34 TuLSA L.J. 15, 40 (1998) (describing R.A.V. as "another of the [Rehnquist's Court's] most important decisions"); Robert G. Schwemm \& Rigel C. Oliveri, A New Look at Sexual Harassment under the Fair Housing Act: The Forgotten Role of $\$ 3604$ (c), 2002 WIS. L. REv. 771, 826-27 (2002) (stating that R.A.V. is the "most important" of cases striking down hate speech regulation).

22. See infra text accompanying notes $232-34$.

23. See infra text accompanying notes $235-48$.

24. Black v. Commonwealth, 553 S.E.2d 738, 741 (Va. 2001).

25. Virginia v. Black, 538 U.S. 343, 348 (2003). 
were expressed and reaffirmed. ${ }^{26}$ Toward the end of the rally, the participants consummated the experience by erecting and igniting a fairly large cross, approximately twenty-five to thirty feet tall. ${ }^{27}$

Black was indicted and convicted of violating Virginia's cross-burning statute. ${ }^{28}$ The statute provides:

It shall be unlawful for any person or persons, with the intent of intimidating any person or group of persons, to burn, or cause to be burned, a cross on the property of another, a highway or other public place. Any person who shall violate any provision of this section shall be guilty of a ... felony.

Any burning of a cross shall be prima facie evidence of an intent to intimidate a person or group of persons. ${ }^{29}$

At Black's trial, the jury was instructed that "the burning of a cross by itself is sufficient evidence from which you may infer the required intent." ${ }^{" 30}$

Richard Elliott and Jonathan O'Mara were also prosecuted under Virginia's cross burning statute after they attempted to burn a cross in the yard of Elliott's neighbor James Jubilee. ${ }^{31}$ Jubilee, who is African-American, had recently moved to the neighborhood and had apparently complained to Elliott's mother regarding the sound of firearms emanating from the Elliott's backyard. ${ }^{32}$ As a retaliatory gesture, Elliott and O'Mara built a "crude wooden cross" and set it ablaze in Jubilee's yard. ${ }^{33}$ Jubilee later discovered the partially burned cross and notified the police. ${ }^{34}$ Elliott and O'Mara were charged with attempted cross burning. ${ }^{35} \mathrm{O}^{\prime} \mathrm{Mara}$ entered a guilty plea to charges of attempted cross burning and conspiracy to commit a felony but reserved the right to challenge the constitutionality of the statute. ${ }^{36} \mathrm{~A}$ jury convicted Elliott on the charge of attempted cross burning. ${ }^{37}$ Elliott's jury did not receive any instructions on the prima facie element of the statute. ${ }^{38}$

The Court of Appeals of Virginia affirmed the convictions, ${ }^{39}$ and the defendants appealed to the Supreme Court of Virginia. ${ }^{40}$ That court found the statute unconstitutional on its face because it discriminated on the basis of content and

26. Id.

27. Black, 553 S.E. $2 d$ at 741.

28. Id.

29. VA. CODE ANN. § 18.2-423 (West 2001).

30. Black, 538 U.S. at 349 .

31. O'Mara v. Commonwealth, 535 S.E.2d 175, 177 (Va. 2000).

32. Black, 553 S.E.2d at 740.

33. Id.

34. O'Mara, 535 S.E.2d at 177.

35. $I d$.

36. Id.

37. Id.

38. Virginia v. Black, 538 U.S. 343 , 351 (2003).

39. O'Mara, 535 S.E.2d at 181.

40. See Black, 553 S.E.2d at 741. 
the speaker's viewpoint, which is impermissible per R.A.V. ${ }^{41}$ The court also concluded that the prima facie evidence portion of the statute is unconstitutional, on overbreadth grounds, because the threat of arrest and prosecution would chill protected expression. ${ }^{42}$

\section{B. THE MAJORITY OPINION}

A fractured Supreme Court affirmed in part and vacated in part. In a striking departure from R.A.V., however, the Court held that though the statute in question was unconstitutional because of the prima facie intent provision, Virginia could in principle prohibit cross burning without violating the First Amendment. ${ }^{43}$ Justice O'Connor wrote the majority opinion for the Court and was joined by Chief Justice Rehnquist and Justices Stevens, Scalia, and Breyer. Justice O'Connor first reviewed the history of cross burnings in the United States and reached the conclusion that "cross burning is often intimidating, intended to create a pervasive fear in victims that they are a target of violence." 44 Justice O'Connor then explained that while content-based distinctions are generally disfavored under the First Amendment, the state may regulate speech on the basis of its content if the state is regulating particular categories of speech ${ }^{45}$ These categories include fighting words, ${ }^{46}$ incitement, ${ }^{47}$ and true threats. ${ }^{48}$ The Court reasoned that burning a cross with the intent to intimidate "is a type of true threat where a speaker directs a threat to a person or group of persons with the intent of placing the victim in fear of bodily harm or death.."49 Finally, the Court rejected the argument that the State should have proscribed all intimidating messages. Relying upon the Court's earlier pronouncement in R.A.V., Justice O'Connor's opinion noted that Virginia could, consistently with the First Amendment, prohibit cross burnings done with the intent to intimidate because Virginia "may choose to regulate [the] subset of intimidating messages" that is "most likely to inspire fear of bodily harm." 50

\section{PRIMA FACIE EVIDENCE COMPONENT}

Justice O'Connor, however, was less favorably disposed toward the prima facie provision of the statute. In a part of her opinion, joined only by Chief Justice Rehnquist and Justices Stevens and Breyer, without Justice Scalia, she

41. See id. at 746.

42. Id.

43. Black, 583 U.S. at 363.

44. Id. at 360 .

45. See id. at $358-359$.

46. Id.

47. Id.

48. Id. at 359 .

49. Id. at 359-360. Justice O'Connor defined a true threat as "statements where the speaker means to communicate a serious expression of an intent to commit an act of unlawful violence to a particular individual or group of individuals." $I d$.

50. Id. at 363 . 
concluded that the Virginia Supreme Court was correct in reversing the conviction of Barry Black because the prima facie element of the statute in conjunction with the jury instruction rendered the statute impermissibly overbroad. ${ }^{51}$

Justice O'Connor argued that the prima facie provision failed to distinguish among the multitudinous messages potentially communicated by cross burning. ${ }^{52}$ She remarked that even though the act of burning a cross is often committed as a method of intimidation, it is not invariably so. "[S]ometimes the cross burning is a statement of ideology, a symbol of group solidarity." ${ }^{353}$ At other times, a burning cross conveys neither ideology, nor solidarity, nor intimidation, and its meaning must be derived from its context. For example, crosses were burned "in movies such as Mississippi Burning, and in plays such as the stage adaptation of Sir Walter Scott's The Lady of the Lake." ${ }^{, 54}$ The prima facie element of the statute "ignore[d] all of the contextual factors that are necessary to decide whether a particular cross burning is intended to intimidate. The First Amendment does not permit such a shortcut. ${ }^{, 55}$

\section{JUSTICE SOUTER'S OPINION}

Justice Souter wrote an opinion, joined by Justices Kennedy and Ginsburg, dissenting from the Court's decision in part and concurring in part. ${ }^{56}$ Justice Souter's principal objection to Virginia's cross-burning statute was that the prima facie evidence portion of the statute was indicative of the State's attempt to stifle unwanted speech. ${ }^{57}$ Justice Souter reasoned that the "primary effect" of the evidence provision "is to skew jury deliberations toward conviction in cases where the evidence of intent to intimidate is relatively weak and arguably consistent with a solely ideological reason for burning." "when the evidence of circumstances fails to point with any clarity either to the criminal intent or to the permissible one," the provision encourages the jury to resolve the doubt in favor of the State. ${ }^{59}$ Consequently, the provision made it more likely that protected speech would be criminalized and legitimate speech suppressed. ${ }^{60}$

Perhaps most objectionable to Justice Souter was the fact that the prima facie provision was demonstrably unnecessary to achieve the State's purpose of banning intimidating statements. As he noted, it "is difficult to conceive of an

51. Id. at 365 .

52. Id.

53. Id. at 366 .

54. Id.

55. Id. at 367 .

56. Id. at 380-87 (Souter, J., dissenting in part and concurring in part).

57. Id. at 386 .

58. Id. at 387 .

59. $I d$. at 386 (stating that "the provision will have the practical effect of tilting the jury's thinking in favor of the prosecution").

60. Id. ("The provision will thus tend to draw nonthreatening ideological expression within the ambit of the prohibition of intimidating expression."). 
intimidation case that could be easier to prove than one with cross burning, assuming any circumstances suggesting intimidation are present." ${ }^{\text {"61 }}$ If the provision was superfluous to the State's legitimate aims, Justice Souter reasoned, the provision's only purpose must have been to communicate to the jury the State's dislike for certain messages. ${ }^{62}$ These messages, such as white supremacy and similar ideologies, are "doubtfully threatening though certainly distasteful," but nonetheless protected by the First Amendment. ${ }^{63}$ Hence, the provision was suspect because it made it more likely than not that protected speech would get criminalized. This was unconstitutional because it was indicative of the State's intent to suppress unpopular, though protected, speech. ${ }^{64}$

\section{R.A.V.}

\section{A. THE FACTS}

The facts of R.A.V. are in some respects quite similar to those of Black. In $R . A . V$., several teenagers "assembled a crudely made cross" and "burned the cross inside the fenced yard" of an African-American family, neighbors of one of the teens. ${ }^{65}$ The city charged R.A.V. with violating St. Paul's anti-crossburning ordinance. ${ }^{66}$ The ordinance provided:

Whoever places on public or private property a symbol, object, appellation, characterization or graffiti, including, but not limited to, a burning cross or Nazi swastika, which one knows or has reasonable grounds to know arouses anger, alarm or resentment on the basis of race, color, creed, religion or gender commits disorderly conduct and shall be guilty of a misdemeanor. ${ }^{67}$

The district court concluded that the statute was overbroad and dismissed the charge. ${ }^{68}$

The Minnesota Supreme Court disagreed. ${ }^{69}$ The court interpreted the ordinance "so as to reach only those expressions of hatred and resorts to biasmotivated personal abuse that the first amendment does not protect," limited the application of the ordinance to fighting words that aroused anger, alarm or resentment on the basis of race, color, creed, religion or gender. ${ }^{71}$ The

61. Id. at 386-87.

62. Id. at 387.

63. Id. at 386.

64. Id.

65. R.A.V. v. City of St. Paul, 505 U.S. 377, 379 (1992).

66. In re Welfare of R.A.V., 464 N.W.2d 507, 508 (Minn. 1991), rev'd sub nom. R.A.V. v. City of St. Paul, 505 U.S. 377 (1992).

67. St. Paul, Minn., LeGis. Code $\$ 292.02$ (1990).

68. Welfare of R.A.V., 464 N.W.2d at 508.

69. Id. at 509.

70. Id. at 511.

71. Id. at 509-10. 
court also reasoned that the ordinance was constitutional "to the extent it prohibits conduct that is 'directed to inciting or producing imminent lawless action and is likely to incite or produce such action." ${ }^{\prime 72}$ So construed, the court upheld the ordinance.

\section{B. THE MAJORITY OPINION}

The United States Supreme Court reversed. Though the Justices unanimously agreed that the ordinance violated the First Amendment, they differed strongly as to the reasoning. Justice Scalia authored the opinion of the Court and was joined by Chief Justice Rehnquist and Justices Kennedy, Souter, and Thomas. Justice Scalia concluded that even if one accepts the limitation on the ordinance imposed by the Minnesota Supreme Court, the ordinance is still facially unconstitutional because it regulates speech on the basis of its content. ${ }^{73}$

Justice Scalia's analysis began with the proposition that, as a general matter, content-based distinctions are presumptively unconstitutional. ${ }^{74}$ The government cannot regulate speech or symbolic speech if the regulation is aimed at the presumed content of that speech. ${ }^{75}$ While the presumption in favor of the unconstitutionality of content-based distinctions is strong, it is not absolute. The state may engage in content-based distinctions "in a few limited" categories, including defamation, obscenity, and fighting words. ${ }^{76}$ Though these categories are of marginal importance to the First Amendment's core interests and their contribution as speech is not always important, they are nevertheless speech. ${ }^{77}$ Consequently, even where the state is regulating proscribable categories, the First Amendment applies still, and content-based restrictions will be permissible only in a few narrow instances. ${ }^{78}$

\section{PERMISSIBLE CONTENT DISCRIMINATION}

The Court delineated four such limited instances where content-based regulations are permissible. First, the state may engage in content discrimination within a regulable category so long as "the basis for the content discrimination consists entirely of the very reason the entire class of speech at issue is proscribable." ${ }^{.79}$ I will term this the primary effects exception: content-based

72. Id. at 510 (quoting Brandenburg v. Ohio, 395 U.S. 444, 447 (1969)).

73. R.A.V., 505 U.S. at 381 ("Assuming, arguendo, that all of the expression reached by the ordinance is proscribable under the 'fighting words' doctrine, we nonetheless conclude that the ordinance is facially unconstitutional in that it prohibits otherwise permitted speech solely on the basis of the subjects the speech addresses.").

74. Id. at 382; see also Police Dep't of Chicago v. Mosley, 408 U.S. 92, 95 (1972) ("[A]bove all else, the First Amendment means that government has no power to restrict expression because of its message, its ideas, its subject matter, or its content.").

75. R.A.V., 505 U.S. at 382 .

76. Id. at 382-83.

77. Id. at $384-85$.

78. Id. at 387 .

79. Id. at 388 . 
regulations within a proscribable category are permissible if the state is regulating the speech on the basis of its primary effects.

Justice Scalia provided three examples to illustrate the contours of the primary effects exception. Consider obscenity, which is a regulable category. The state may draw lines within that category-discriminating for example among the least obscene, obscene and most obscene speech-if the state is concerned about the effects of truly obscene speech. ${ }^{80}$ The state may not, however, prohibit "only that obscenity which includes offensive political messages." 81 Similarly, the state may specifically prohibit threats of violence against the President "since the reasons why threats of violence are outside the First Amendment (protecting individuals from the fear of violence, from the disruption that fear engenders, and from the possibility that the threatened violence will occur) have special force when applied to the person of the President." ${ }^{, 82}$ In contrast, the state cannot prohibit "only those threats against the President that mention his policy on aid to inner cities" without violating the First Amendment because the President's policies on inner cities is unrelated to the reason why threats of violence against the President are proscribable. ${ }^{83}$ Lastly, the state may regulate commercial speech, for example price discrimination, "because the risk of fraud (one of the characteristics of commercial speech that justifies depriving it of full First Amendment protection) is in its view greater there." ${ }^{.84}$ But the government cannot "prohibit only that commercial advertising that depicts men in a demeaning fashion." 85

Second, the state may also engage in content discrimination within a regulable category where the state is concerned about the "secondary effects" of the speech. ${ }^{86}$. So the state may permissibly prohibit adult motion picture theaters within 1,000 feet of a school if the purpose of the regulation is to limit crime and to maintain surrounding property values. ${ }^{87}$

Third, the R.A.V. Court also noted an incidental effects exception. If the state's regulation is aimed at the individual's conduct, the regulation is not subject to heightened scrutiny simply because a "particular content-based subcategory of a proscribable class of speech" is "swept up incidentally within the reach" of the legislation. ${ }^{88}$ The state may prohibit "sexually derogatory "fighting words" in a statute aimed at eliminating sexual discrimination in employment. ${ }^{89}$ Or the state may provide greater criminal sanctions for bias-motivated

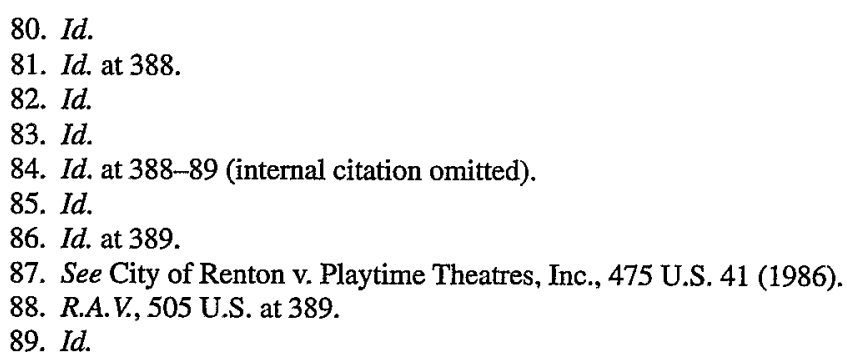


crimes. $^{90}$

Finally, the state may engage in content discrimination provided that "the nature of the content discrimination is such that there is no realistic possibility that official suppression of ideas is afoot." ${ }^{91}$ Hence, Justice Scalia explained, "We cannot think of any First Amendment interest that would stand in the way of a State's prohibiting only those obscene motion pictures with blue-eyed actresses." 92

\section{ANALYSIS OF THE ORDINANCE}

Turning to St. Paul's ordinance, the Court concluded that it violated the First Amendment for two reasons. First, the ordinance was impermissibly contentbased. It drew a line across various content categories and located on one side of the line the categories of race, religion, and gender, while all other categories lay on the other side of the line. ${ }^{93}$

Second, the ordinance discriminated on the basis of the speaker's viewpoint. The St. Paul ordinance prohibited those speakers who disagreed with the city's message of racial, gender, and religious tolerance from using fighting words in favor of their position. However, those individuals who support the city's message of tolerance could use fighting words in favor of their position. Thus, "[o]ne could up a sign saying, for example, that all "anti-Catholic bigots" are misbegotten, but not that all "papists" are, for that would insult and provoke violence "on the basis of religion." "Justice Scalia concluded, "St. Paul has no such authority to license one side of a debate to fight freestyle, while requiring the other to follow Marquis of Queensberry rules."95

Though the ordinance was content-based, it could have been saved if it could fit under one of the exceptions to content-based regulations. The ordinance, however, could not so be saved. The Court first noted that the ordinance could not come within the ambit of the primary-effects exception because the city did not select "an especially offensive mode of expression" such as "fighting words

90. See Wisconsin v. Mitchell, 508 U.S. 476 (1993) (holding that a Wisconsin statute that enhanced sentence for crime against a victim intentionally selected because of race did not violate defendant's First Amendment rights).

91. R.A.V., 505 U.S. at 390.

92. Id. at 390 .

93. Justice Scalia remarked:

Displays containing abusive invective, no matter how vicious or severe, are permissible unless they are addressed to one of the specified disfavored topics. Those who wish to use "fighting words" in connection with other ideas - to express hostility, for example, on the basis of political affiliation, union membership, or homosexuality - are not covered. The First Amendment does not permit St. Paul to impose special prohibitions on those speakers who express views on disfavored subjects.

Id. at 391.

94. Id at 391-92.

95. Id. at 392. 
that communicate ideas in a threatening ... manner." ${ }^{\text {96 }}$ Instead, the City sought to ban "obnoxious" expressions- "fighting words of whatever manner that communicate messages of racial, gender, or religious intolerance." ${ }^{97}$ Because St. Paul attempted to regulate speech directly, as opposed to regulating the secondary effects of speech, or incidentally regulating speech by targeting certain conduct, the ordinance could not be saved by any of the other bases upon which the state may permissibly engage in content-based regulations within a proscribable category. ${ }^{98}$

\section{UNDERSTANDING R.A.V.}

R.A.V. is admittedly a difficult case to understand. In R.A.V., Justice Scalia "reach[ed] out unnecessarily ... to condemn the government's motives, despite the narrower available alternative of simply whittling down the excessive scope of the punished speech." ${ }^{.99}$ Additionally, in the process of resolving the case "on a ground that require[d] serious departures from the teaching of prior cases, ${ }^{, 100}$ the Court created a novel doctrinal framework that has been criticized by many. ${ }^{101} R . A . V$. 's opacity is due in part to the majority's failure to fully explicate its concerns with St. Paul's ordinance. However, once one comes to terms with the Court's underlying concern, R.A.V.'s meaning becomes much more transparent. Section A examines Justice Scalia's doctrinal framework in R.A.V., and concludes that even though Justice Scalia's justification for his framework is plausible, it is ultimately unsatisfying. Section B offers a different justification than the Court provided in R.A.V. for its doctrinal framework. I justify the Court's doctrinal approach as underscoring the importance of state justifications-the requirement that the state provide legitimate reasons for its classifications-in First Amendment jurisprudence. Section C argues that R.A.V. reflects the majority's deep skepticism that the government is regulating cross burning in order to address a legitimate harm. R.A.V. represents a suspicion that statutes targeting cross burnings are invariably aimed at enforcing a politically correct viewpoint while concomitantly suppressing racist speech that the state disapproves. Hence, R.A.V. stands for the proposition that statutes targeting cross burning are per se unconstitutional. This understanding of R.A.V. best explains Justice Scalia's decision to promulgate a novel doctrinal framework as opposed to deciding the case on overbreadth grounds.

96. Id. at 393 .

97. Id. at 393-94.

98. Id. at 394-95.

99. Sullivan, supra note 16 , at 104.

100. R.A.V. v. City of St. Paul, 505 U.S. 377, 398 (1992) (White, J., concurring).

101. See Steven H. Shiffrin, Dissent, Inuustice, and the Meanings of America $49-87$ (1999) (describing how the Court "bungled the First Amendment job" in R.A.V.); Erwin Chemerinsky, Content Neutrality as a Central Problem of Freedom of Speech: Problems in the Supreme Court's Application, 74 S. CAL. L. REv. 49, 63-64 (2000) (characterizing the consequences of Scalia's approach as "undesirable"); Heyman, supra note 21, at 714 (calling Scalia's approach "unwise"). 


\section{A. JUSTICE SCALIA'S SUPERFICIALLY PLAUSIBLE FRAMEWORK}

Justice Scalia's opening move is the non-controversial assertion that contentbased laws are presumptively unconstitutional because the government may not regulate speech on the basis of hostility or favoritism to the content of the speech. ${ }^{102}$ However, as most students of the First Amendment recognize, there are many categories of speech that the government may regulate on the basis of its content-for example, fighting words, obscenity, threats-without running afoul of the First Amendment. ${ }^{103}$ This fact, prior to R.A.V., gave rise to the view that the scope of the First Amendment's protection did not extend to certain categories of content-based regulations because expression falling within those categories did not reflect the "values the First Amendment was designed to protect." 104

Justice Scalia conceded that the Court's precedents excluded certain areas of speech from the purview of the First Amendment, ${ }^{105}$ but he attempted to minimize that concession on the ground that the language used in those cases "must be taken in context." 106 The Court, he intimated, could not have meant and did not mean what it appeared to say in those cases: ${ }^{107}$ Instead, the Court intended to communicate that certain areas of speech can be regulated because of their content, not because they constitute non-speech. ${ }^{108}$ Thus, while the government may regulate proscribable categories, it can only do so within the shadow of the First Amendment. ${ }^{109}$

Though the concurring Justices correctly noted that the majority's conclusion was inconsistent with the Court's prior pronouncements on regulable categories under the First Amendment, ${ }^{110}$ the majority's insistence that regulable categories, such as fighting words, obscenity, and true threats, constitute speech is not

102. R.A.V., 505 U.S. at 382.

103. Virginia v. Black, 538 U.S. 343,358 (2003) ("The protections afforded by the First Amendment, however, are not absolute, and we have long recognized that the government may regulate certain categories of expression consistent with the Constitution."); Chaplinsky v. New Hampshire, 315 U.S. 568, 571-72 (1942) ("There are certain well-defined and narrowly limited classes of speech, the prevention and punishment of which has never been thought to raise any Constitutional problem.").

104. R.A.V., 505 U.S. at 399 (White, J., concurring).

105. See id. at 400 (citing Roth v. United States, 354 U.S. 476, 483 (1957); Beauharnais v. Illinois, 343 U.S. 250, 266 (1952); Chaplinsky v. New Hampshire, 315 U.S. 568, 571-72 (1942); Bose Corp. v. Consumers Union, 466 U.S 485, 504 (1984); and Sable Communications of Calo, Inc. v. FCC, 492 U.S. $115,124(1989))$.

106. R.A.V., 505 U.S. at 383.

107. See id. (stating that the Court's prior statements are not literally true).

108. Justice Scalia stated:

[T]hese areas of speech can, consistently with the First Amendment be regulated because of their constitutionally proscribable content (obscenity, defamation, etc.)-not that they are categories of speech entirely invisible to the Constitution, so that they may be made the vehicles for content discrimination unrelated to their distinctively proscribable content.

II. at 383-84.

: 109. Id. at 384 .

110. Id. at 398 (White, J., concurring) (noting that the Court's analysis "requires serious departures from the teaching of prior cases"). 
without merit. ${ }^{111}$ These categories are both expressive and communicative. ${ }^{112}$ The Court's prior declarations on the constitutional status of regulable categories were indeed intellectually sloppy, and Justice Scalia's claim that the government cannot regulate speech on the basis of favoritism or hostility to the content of the speech is thought by some to constitute a bedrock principle of the First Amendment. ${ }^{113}$

However, the R.A.V. Court is less clear as to why regulating certain categories is consistent with the First Amendment. Justice Scalia provided two distinctive reasons for the subordinate status of regulable categories such as fighting words. ${ }^{114}$ The first part of the opinion justifies the categorical approach on the theory that such categories may be regulated on the basis of their content:

[O]ur society, like other free but civilized societies, has permitted restrictions upon the content of speech in a few limited areas, which are "of such slight social value as a step to truth that any benefit that may be derived from them is clearly outweighed by the social interest in order and morality."115

Yet, this first explanation is inconsistent with the thrust of Justice Scalia's opinion. After all, an important component of the majority's purpose in R.A.V. is establishing the proposition that proscribable categories cannot be regulated simply because the state disagrees with the message. Moreover, the explanation is particularly at odds with the majority's later assertion that it "is not true that [regulable categories] have at most a 'de minimis' expressive content ... or that their content is in all respects 'worthless and undeserving of constitutional

111. Id. at 417 (Stevens, J., concurring) (noting that while the Court has in previous opinions maintained that regulable categories are outside of the purview of the First Amendment, it has "quite rightly" deviated from those categorical statements).

112. As Dean Kagan noted, "though courts often claim that fighting words and other unprotected speech have no expressive content or function, these claims ought not to be taken at face value.... Claims to the contrary serve as shorthand for a complex calculation that the harms of such speech outweigh their contribution to the sphere of expression." Elena Kagan, Private Speech, Public Purpose: The Role of Governmental Motive in First Amendment, 63 U. CHI. L. REv. 413, 419 (1996).

113. Steven D. Hinckley, Your Money or Your Speech: The Children's Internet Protection Act and the Congressional Assault on the First Amendment in Public Libraries, 80 WASH. U. L.Q. 1025, 1074' (2002) (referring to the "bedrock principle that the government may not place restrictions on expression simply because it finds the ideas expressed to be offensive or disagreeable."); Geoffrey R. Stone, Content Regulation and the First Amendment, 25 WM. \& MARY L. REv. 189, 196 (1983) (tracing the rise of the distinction between content-based and content-neutral restrictions as a governing principle).

In an oft-quoted declaration, for example, the Court announced in Police Department of Chicago $v$. Mosley, 408 U.S. 92, 95 (1972), that "above all else, the First Amendment means that government has no power to restrict expression because of its message, its ideas, its subject matter, or its content." Although this declaration has proved to be somewhat overstated, the Court has been remarkably true to its word, for except when low value speech is at issue, the Court has invalidated almost every content-based restriction that it has considered in the past quarter-century. Stone, supra, at 196-97.

114. See R.A.V., 505 U.S. at 383 (listing regulable categories).

115. Id. at 383 (quoting Chaplinsky v. New Hampshire, 315 U.S. 568, 572 (1942)). Similarly, he explained, "these areas of speech can, consistently with the First Amendment, be regulated because of their constitutionally proscribable content (obscenity, defamation, etc.)." Id. 
protection." $" 116$

Toward the end of the opinion, Justice Scalia offered a second rationale: "the reason why [certain categories] are ... excluded from the protection of the First Amendment is not that their content communicates any particular idea, but that their content embodies a particularly intolerable (and socially unnecessary) mode of expressing whatever idea the speaker wishes to convey." 117 These categories, such as "fighting words," are akin to a noisy sound truck. ${ }^{118}$ Like a noisy sound truck, fighting words constitute a manner of speaking that can be used to communicate an idea, but it is not a manner that necessarily has "a claim upon the First Amendment."119

Even so, though fighting words (and other regulable categories) may be similar to a noisy sound truck in terms of their communicative value, "the government may not regulate their use based on hostility-or favoritismtowards the underlying message expressed." ${ }^{120}$ On the strength of this proposition, Justice Scalia deduced the contentious precept that even where the government is legislating within a regulable category, it cannot engage in additional and discrete content-based distinctions. ${ }^{121}$ Strict scrutiny is applicable to content-based regulations within proscribable categories. This proposition served as the necessary linchpin of the R.A.V. majority.

This move led Justice White to lament the majority's doctrinal framework, which Justice White characterized as specious. ${ }^{122}$ If the government can proscribe an entire category of speech, it necessarily follows that it can proscribe a subset of that category. ${ }^{123}$ By definition, "the content of the subset is ... worthless and undeserving of constitutional protection." 124

The majority offered a response, though it failed to offer a reason to support its holding that the First Amendment restricts the state's ability to engage in content-based restrictions within proscribable categories. ${ }^{125}$ Instead, Justice Scalia provided a series of quirky examples purportedly intended to illustrate the truth of the principle. If the state were not prohibited from engaging in content discrimination within proscribable categories, the Court would be powerless to strike down a number of hypothetical state regulations that patently violate the First Amendment. For example, the Court would have to uphold "an ordinance prohibiting only those obscene works that contain criticism of the city

116. $I d$. at 384-85.

117. Id. at 393 .

118. Id. at 386 .

119. $I d$.

120. $I d$.

121. $I d$.

122. Id. at 401 (White, J., concurring) ("It is inconsistent to hold that the government may proscribe an entire category of speech because the content of that speech is evil, but that the government may not treat a subset of that category differently without violating the First Amendment.").

123. Id.

124. $I d$.

125. Justice Scalia failed to provide a single case to support the proposition. 
government or, indeed, that do not include endorsement of the city government"126 on the ground that the city may regulate obscenity. The Court would have to sanction a state law prohibiting "only that obscenity which includes offensive political messages." ${ }^{.27}$ The Court would also have to countenance a federal law criminalizing "threats against the President that mention his policy on aid to inner cities" on the ground that the federal government may legitimately criminalize threats of violence against the President. ${ }^{128}$ Since the Court would not uphold those regulations, one must conclude that the state cannot engage freely in content-based discriminations within proscribable categories without implicating the First Amendment.

The Court's approach in R.A.V. is not without its critics. ${ }^{129}$ Many commentators, including the concurring Justices, have condemned Justice Scalia's opinion for fashioning a doctrine where none had existed, instead of deciding the case on overbreadth grounds. ${ }^{130}$ For example, Justice White derisively referred to R.A.V.'s principle as "the Court's new 'underbreadth' creation,"131 and Justice Stevens poked fun at the majority's doctrinal framework by categorizing it as "something of an adventure in a doctrinal wonderland."132

\section{B. THE IMPORTANCE OF STATE JUSTIFICATIONS}

Despite the criticism, was Justice Scalia right? Does the fact that the Court would not support any of his hypothetical regulations logically establish the principle that states may not freely engage in content-based distinctions within proscribable categories? As this Section shows, the essence of Justice Scalia's doctrinal approach is on target, though his precise formulation and the reasons that support his doctrinal framework may leave something to be desired.

Consider this proposition as an alternative explanation for the examples that Justice Scalia provided: The government may not regulate speech without sufficient justification. This alternative proposition also comes with a corollary: Hostility toward speech is not a compelling justification under the First Amendment. ${ }^{133}$ Concededly, this principle and its corollary are less profound and more

126. 505 U.S. at 384 .

127. Id. at 388 .

128. Id. at 388-89.

129. See, e.g., Charles R. Lawrence III, Crossburning and the Sound of Silence: Antisubordination Theory and the First Amendment, 37 VILL. L. Rev. 787 (1992).

130. G. Sidney Buchanan, The Hate Speech Case: A Pyrrhic Victory for Freedom of Speech?, 21 Hofstra L. Rev. 285, 309-10 (1992) (describing overbreadth as "the clear and preferred basis" for decision).

131. R.A.V., 505 U.S. at 402 (White, J., concurring).

132. Id. at 418 (Stevens, J., concurring).

133. The Court has maintained on numerous occasions that the state may not regulate speech if its purpose is to suppress a viewpoint or to enforce its own orthodox viewpoint. W. Va. State Bd. of Educ. v. Barnette, 319 U.S. 624, 642 (1943) ("If there is any fixed star in our constitutional constellation, it is that no official, high or petty, can prescribe what shall be orthodox in politics, nationalism, religion, or other matters of opinion or force citizens to confess by word or act their faith therein."); Rosenberger v. Rector \& Visitors of the Univ. of Va., 515 U.S. 819, 828-30 (1995). 
pedestrian than the principle announced in R.A.V. The alternative principle, however, is more persuasive, obvious, and reasonable. ${ }^{134}$

Justice Scalia's examples demonstrate that justifications matter in First Amendment doctrine. ${ }^{135}$ Put differently, the government does not violate the First Amendment when it can offer a "legitimate, reasonable, and neutral justification[]" for the regulation. ${ }^{136}$ When government action infringes upon protected speech, it must provide a satisfactory justification for the infringement. Where the government's justifications are not sufficient, the Court will not uphold the regulation at issue. Phrased in those terms, R.A.V.'s doctrinal approach does not appear to be such a radical departure from modern First Amendment jurisprudence.

Police Department of Chicago v. Mosley $y^{137}$ and Carey v. Brown ${ }^{138}$ are analogous cases that help prove the point. In both cases, the plaintiffs challenged a residential picketing statute that prohibited residential picketing but created an exception for labor picketing. ${ }^{139}$ In Mosley, the government justified the distinction as necessary "for preventing disruption of the school."140 In

134. Professor Schauer has recently explained, "contrary to how the Court understood the issue in R.A.V., it is sounder to think of the distinctions [made in R.A.V.] in light of a First Amendment not that protects speech, but instead that prohibits certain reasons for restricting it." Frederick Schauer, Intentions, Conventions, and the First Amendment: The Case of Cross-Burning, 2003 SuP. CT. REv. $197,207$.

135. See generally, Kagan, supra note 113.

136. R.A.V., 505 U.S. 416 (Stevens, J., concurring).

137. 408 U.S. 92 (1972). For seven months before Chicago enacted an ordinance prohibiting picketing within 150 feet of a school while the school is in session, Earl Mosley maintained a one-man picket against a Chicago high school. Id. at 93. Mosley carried a sign stating that "Jones High School practices black discrimination. Jones High School has a black quota." Id. The ordinance exempted from its purview "the peaceful picketing of any school involved in a labor dispute." Id. at 93-94. After the ordinance became effective, Mosely filed a lawsuit in federal court challenging the constitutionality of the statute. In particular, Mosely complained that the provision exempting labor picketing from the statute's general prohibition against picketing violated his First and Fourteenth Amendment rights. Id. at 94.

138. 447 U.S. 455 (1980). The defendants, who were protesting the City's refusal to bus students as a means of integrating the City's public schools, had previously been arrested for violating the statute after they picketed the home of Chicago's mayor. Id. at 457. They argued that the statute violated their First and Fourteenth Amendment rights. Id.

139. Mosley, 408 U.S. at 93-94; Brown, 447 U.S. at 457-59. The statute in Mosley stated in part:

A person commits disorderly conduct when he knowingly: (i) Pickets or demonstrates on a public way within 150 feet of any primary or secondary school building while the school is in session and one-half hour before the school is in session and one-half hour after the school session has been concluded, provided, that this subsection does not prohibit the peaceful picketing of any school involved in a labor dispute.

Mosley, 408 U.S. at 92-93 (quoting ChICAGo, Irl., Mun. Code, ch. 193-1(i) (1968)). The statute in Brown provided that:

It is unlawful to picket before or about the residence or dwelling of any person, except when the residence or dwelling is used as a place of business. However, this Article ... does not prohibit the peaceful picketing of a place of employment involved in a labor dispute ... .

Brown, 447 U.S. at 457 (quoting ILL. Rev. STAT., ch. 38, § 21.1-2 (1977)).

140. Mosley, 408 U.S. at 99. 
Brown, the state argued that the statute was indispensable to safeguarding residential tranquility. ${ }^{141}$ In both cases the government argued that labor picketing was less disruptive than non-labor picketing. ${ }^{142}$

In both cases, the Court agreed that the government was regulating pursuant to an important governmental interest. ${ }^{143}$ The Court also noted that the speech targeted by the statutes fell within a regulable category. ${ }^{144}$ However, the statutes were also content-based and thus required a justification. ${ }^{145}$

The Court concluded that the statutes were unconstitutional because the state could not provide a legitimate or neutral justification for the content-based discrimination. ${ }^{146}$ The Court maintained that the basis for the labor/non-labor distinction was "improper content censorship." 147 From the Court's perspective, the exemption contained in the statutes reflected the government's impermissible motive. ${ }^{148}$ "[G]overnment may not grant the use of a forum to people whose views it finds acceptable, but deny the use to those wishing to express less favored or more controversial views."149 Thus, the Court maintained, "above all else, the First Amendment means that government has no power to restrict expression because of its message, its ideas, its subject matter, or its content." 150

As Mosley and Brown demonstrate, the government's ability to permissibly regulate a certain area of speech does not necessarily preclude an inquiry into the government's motives and an evaluation of the government's justifications. Because the statutes were both over- and underinclusive, the Court questioned the state's proffered explanation. ${ }^{151}$ Since the state's explanation did not comport with the statutory scheme, speech suppression best explained the govern-

141. Brown, 447 U.S. at 454.

142. Mosley, 408 U.S. at $100 ;$ Brown, 447 U.S. at 465.

143. See Mosley, 408 U.S. at 98,100 ; Brown, 447 U.S. at 471.

144. See Mosley, 408 U.S. at 99 (noting that time, place, and manner restrictions, or other regulations necessary to preserve public order, are legitimate); Brown, 447 U.S. at 470-71 (quoting Gregory v. Chicago, 394 U.S. 111, 118 (1969) (Black, J. concurring) ("[N]o mandate in our Constitution leaves States and governmental units powerless to pass laws to protect the public from the kind of boisterous and threatening conduct that disturbs the tranquility of spots selected by the people either for homes. . . or for public and other buildings that require peace and quiet to carry out their functions, such as courts, libraries, schools, and hospitals.")).

145. See Mosley, 408 U.S. at 95, 99; Brown, 447 U.S. at 460-61 ("On its face, the Act accords preferential treatment to the expression of views on one particular subject; information about labor disputes may be freely disseminated, but discussion of all other issues is restricted.").

146. See Mosley, 408 U.S. at 102; Brown, 447 U.S. at 471.

147. See Mosley, 408 U.S. at 99; see also Brown, 447 U.S. at 462.

148. See Mosley, 408 U.S. at 96.

149. Id.

150. Id. at 95 .

151. Id. at 100 ("Although preventing school disruption is a city's legitimate concern, Chicago itself has determined that peaceful labor picketing during school hours is not an undue interference with school. Therefore, under the Equal Protection Clause, Chicago may not maintain that other picketing disrupts the school unless that picketing is clearly more disruptive than the picketing Chicago already permits."); Brown, 447 U.S. at 465 ("The apparent overinclusiveness and underinclusiveness of the statute's restriction would seem largely to undermine appellant's claim that the prohibition of all 
ment's true motive. ${ }^{152}$

Returning to R.A.V.'s hypothetical speech restrictions, one can offer an alternative reason to explain why such laws would be unconstitutional. A city ordinance prohibiting obscene art that is critical of the city council is unconstitutional not because the state may not engage in content-based discrimination when it is regulating in a proscribable category-in this case obscenity-but rather because the ordinance singles out obscene political speech, indicating that the government's real motive is the regulation of political speech. In other words, the government's proffered justification, that it is really interested in regulating obscene speech, is belied by the government's singling out political speech for regulation.

Similarly, a federal statute that criminalized only threats against the President's policy on an issue of national importance would violate the First Amendment because it would regulate core political speech without sufficient justification. Once again, singling out threatening political speech for regulation illustrates the government's illicit motive: regulation of political speech. The government would not be able to offer a sufficiently compelling or plausible justification for the distinction. In the absence of a reasonable justification, one must sensibly conclude that the government is not regulating speech because of concern about obscenity or threats; rather, the government is using the proscribable category as a pretext for regulating protected speech. ${ }^{153}$

Perhaps more importantly, the principle that government may not regulate speech without sufficient justification explains the majority's decision in R.A.V. better than the principle proclaimed by Justice Scalia. Justice Scalia's opinion is least persuasive in its attempt to cabin the reach of his principle and distinguish the facts of R.A.V. from seemingly similar contexts. Justice Scalia addressed two such contexts: threats against the President and "sexually derogatory "fighting words' ... [in] violation of Title VII's general prohibition against sexual discrimination in employment practices." 154

Justice Scalia explained that threats against the President fell within the primary-effects exception because "the reasons why threats of violence are outside the First Amendment (protecting individuals from the fear of violence, from the disruption that fear engenders, and from the possibility that the threatened violence will occur) have special force when applied to the person of

nonlabor picketing can be justified by reference to the State's interest in maintaining domestic tranquility.").

152. Mosley, 408 U.S. at 100-01; Brown, 447 U.S. at 465.

153. Schauer, supra note 134, at 11 ("From this perspective what is wrong with the ... distinctions is ... that they are based on reasons and distinctions - between viewpoints, most notably-that the First Amendment simply cannot countenance, and that the distinctions that are ... [permissible] are acceptable because, by being based on distinctions that support the doctrinal structure itself, they reflect reasons the First Amendment does not deem impermissible.").

154. R.A.V. v. City of St. Paul, 505 U.S. 377, 388-89 (1992) (citing 42 U.S.C. $\$ 2000 \mathrm{e}-2$ (2000); 29 CFR § 1604.11 (1991)). 
the President."155 Additionally, as Justice Souter added in Black, "[d]ifferential treatment of threats against the President ... selects nothing but special risks, not special messages." 156 If Justices Scalia and Souter are right, then statutes prohibiting cross burning cannot be distinguished from statutes prohibiting threats of violence against the President. As Justice Stevens remarked:

Precisely this same reasoning ... compels the conclusion that St. Paul's ordinance is constitutional. Just as Congress may determine that threats against the President entail more severe consequences than other threats, so St. Paul's City Council may determine that threats based on the target's race, religion, or gender cause more severe harm to both the target and to society than other threats. This latter judgment-that harms caused by racial, religious, and gender-based invective are qualitatively different from that caused by other fighting words-seems to me eminently reasonable and realistic. ${ }^{157}$

Moreover, it is reasonable to assume that racial, ethnic, and religious minorities are at greater risk of being targeted by cross burners than are racial, ethnic, and religious majorities. Thus, outlawing cross burning would be justified on the grounds that cross burning is uniquely directed against minorities.

Justice Scalia's attempt to distinguish Title VII hostile work environment claims from cross burning claims under the First Amendment is similarly unpersuasive. Under Justice Scalia's reasoning, Title VII passes muster under the First Amendment, despite an explicit content-based distinction within a regulable category, because the statute falls under the secondary-effects exception of R.A.V. ${ }^{158}$ Justice Scalia argued that Title VII is not vulnerable to constitutional attack under the First Amendment because the statute is directed at conduct and not speech. ${ }^{159}$ Title VII admittedly impacts speech, but this impact is permissible because it is incidental to regulating conduct. ${ }^{160}$

One can easily advance an analogous argument with respect to cross burning statutes. As a preliminary matter, note that "the overwhelming proportion of hostile environment cases are ones in which words or pictures are a significant part of the circumstances that create a hostile environment." 161 This empirical reality belies the contention that sexual harassment claims are directed primarily

155. Id. at 388 .

156. Virginia v. Black, 538 U.S. 343, 384 (2003) (Souter, J., concurring in the judgment in part and dissenting in part).

157. R.A.V., 505 U.S. at 424 (Stevens, J., concurring in the judgment),

158. Id. at 390 ("Where the government does not target conduct on the basis of its expressive content, acts are not shielded from regulation merely because they express a discriminatory idea or philosophy.").

159. Id. at 389. For a further and more expansive development of this point, see CATHARINE A. MaCKInNON, ONLY Words 45-68 (1993).

160. R.A.V., 505 U.S. at 389.

161. Frederick Schauer, The Speech-ing of Sexual Harassment, in DiRECTIONS IN SEXUAL HaRAsSMENT LAw 347, 352 (Catherine A. MacKinnon \& Reva B. Siegel eds., 2004). 
at conduct and secondarily or incidentally towards speech. ${ }^{162}$ In contrast, leaving aside the question of whether cross-burning statutes are directed at constitutionally protected messages, those statutes undoubtedly regulate conduct: the act of cross burning. Thus, it is not clear why a statute that targets sex-based "hate speech" in the workplace is directed at conduct but not speech, whereas a statute targeting race-based "hate speech" is directed at speech but not conduct. On the contrary, one would think that a statute that prohibits cross burning comes closer to regulating conduct than a statute that regulates sexual harassment in the workplace.

One can avoid these ad hoc distinctions by recognizing the importance of the government's justification in R.A.V. Regardless of Justice Scalia's adamant assertion in R.A.V. that a state may not engage in additional content-based regulations within a prohibited category, the Court's fundamental objection to the St. Paul ordinance was the belief that the government singled out cross burning not because of the harm that cross burning caused-a legitimate justification - but because the government disagreed with the message communicated by cross burnings-an illegitimate justification. Justice Scalia reasoned that the city's purpose in passing the ordinance was to "display[] the city council's special hostility towards" white supremacist and bias-motivated hate speech $^{163}$ and to "communicate to minority groups that the 'group hatred" aspect of such speech 'is not condoned by the majority." 164 The city's attempt to manipulate the content of speech suggested a "realistic possibility that official suppression of ideas is afoot." 165 Thus, the R.A.V. Court ultimately concluded that the ordinance was unconstitutional because "the city is seeking to handicap the expression of particular ideas," a goal that is intolerable under the First Amendment. ${ }^{166}$ Message suppression is not a legitimate justification. In this regard, R.A.V. must be understood as the Court's statement against political correctness and hate speech legislation, which can be otherwise characterized as state-enforced orthodoxy.

162. In fact, some scholars have seized upon this speech component to argue that statutes prohibiting hostile work environment sexual harassment violate the First Amendment. See, e.g., Eugene Volokh, What Speech Does "Hostile Work Environment" Harassment Law Restrict?, 85 GEo. L.J. 627 (1997) Eugene Volokh, Freedom of Speech and Workplace Harassment, 39 UCLA L. REv. 1791 (1992). My point here is not that hostile work environment harassment claims are inconsistent with the First Amendment. Rather, my point is that Justice Scalia's attempt to distinguish the First Amendment status of those claims from the First Amendment status of cross burning claims is difficult to sustain. As Professor Schauer explains, the First Amendment status of sexual harassment claims cannot be explained by First Amendment doctrine, as Justice Scalia attempted to do. To understand the constitutional status of sexual harassment claims (presumably as well as cross burning claims), one "cannot ignore the role of politics, culture, economics, and numerous other social forces in determining which forms of word-based conduct inspire First Amendment rhetoric and standards and which do not." Schauer, supra note 161, at 348 .

163. R.A.V., 505 U.S. at 396.

164. Id. at 392 (quoting Brief for Respondent at 25, R.A.V. v. City of St. Paul, 505 U.S. 377 (1992) (No. 90-7675)).

165. See id. at 390 .

166. Id. at 394. 


\section{CROSS-BURNING STATUTES AND THE EPISTEMIC DILEMMA}

R.A.V. must also be understood as the Court's attempt to constitutionalize its distrust of the state. To best appreciate this point, consider that cross-burning statutes present an interesting epistemic dilemma for First Amendment jurisprudence. The epistemic question for the Court is determining when and whether it should believe the state's proffered explanation for promulgating a particular regulation that raises First Amendment concerns. ${ }^{167}$ As the Black Court recognized, a burning cross communicates at least two distinct, though not necessarily unrelated, messages. ${ }^{168} \mathrm{~A}$ burning cross may communicate a socio-political racist message of white supremacy ${ }^{169}$ or a threat to an intended victim, ${ }^{170}$ or it may do both. ${ }^{171}$ While the state cannot target cross burning because it disagrees with the message of white supremacy that the burning cross may communicate, ${ }^{172}$ it can proscribe cross burnings if its purpose is to suppress the threat communicated by cross burnings. ${ }^{173}$ Thus, courts are obliged to defer to the state's justification where the state is regulating cross burning on a permissible basis. At the same time, courts must be vigilant to guard against state-imposed orthodoxy.

As an illustrative exercise, compare flag burning with cross burning. Flag burning presents a straightforward case for judicial resolution because government justifications of flag-burning statutes are not entitled to any epistemic deference whatsoever. Courts do not believe that the state has greater knowledge about the way the world works with respect to burning flags than do judges. In fact, statutes regulating flag burning engender judicial skepticism. Consider in this vein Texas v. Johnson. ${ }^{174}$

In Johnson, the Supreme Court held that Texas infringed upon Gregory Lee Johnson's First Amendment rights when it convicted him for violating a statute prohibiting desecration of the flag. ${ }^{175}$ The Texas statute provided that a person could not "deface, damage, or otherwise physically mistreat [a state or national flag] in a way that the actor knows will seriously offend one or more persons

167. For a fuller discussion of epistemic authority, see infra text accompanying notes 262-272.

168. See Virginia v. Black, 538 U.S. 343, 365 (2003); see also id. at 381 (Souter, J., concurring in the judgment in part and dissenting in part).

169. The prototypical example here is the KKK member who burns a cross on the lawn of a black family.

170. Consider a hypothetical in which the cross burner and the intended victim are both African Americans. In that scenario, the burning cross would signal an intent to harm, but not a message of white supremacy. A black person who burned a cross on the lawn of another black person would not be communicating a message of racial supremacy, but one of threat.

171. See Black, 538 U.S. at 354-56, 363.

172. See R.A.V. v. City of St. Paul, 505 U.S. 377, 392 (1992); see also id. at 386 (noting that "the power to proscribe [speech] on the basis of one content element (e.g., obscenity) does not entail the power to proscribe it on the basis of other content elements").

173. See id. at 386.

174. 491 U.S. 397 (1989).

175. See id. at 399. 
likely to observe or discover his action." ${ }^{176}$ Johnson was charged with violating the statute after burning a flag during a political demonstration. ${ }^{177}$

Texas offered two justifications for its statute: it wanted to prevent disturbances of the peace, and it wanted to maintain "the flag as a symbol of ... national unity." ${ }^{178}$ The Court discounted the first justification as unworthy of belief and dismissed the second justification as incompatible with the First Amendment. ${ }^{179}$

The Court rejected the State's argument that the statute was necessary for the maintenance of peace and order for three reasons. First, the Court examined the record and concluded that "no disturbance of the peace actually occurred or threatened to occur" in reaction to Johnson's burning of the flag. ${ }^{180}$ Consequently, the Court expressed skepticism about the claim that actual disturbances justified either the statute or the prosecution of Johnson.

Second, the State could not justify the statute on the assumption that disturbances would occur because flag burning is likely to arouse the passions and provoke a violent reaction from onlookers. ${ }^{181}$ The Court explained that the government is not permitted to "assume that every expression of a provocative idea will incite a riot." 182 Indeed, an important purpose of speech, the Court exclaimed, is to provoke "a condition of unrest, create[] dissatisfaction with conditions as they are, or even stir[] people to anger." 183 A state may not regulate speech on the basis of non-speakers' reaction until it evaluates carefully "the actual circumstances surrounding such expression, asking whether the expression 'is directed to inciting or producing lawless action and is likely to incite or produce such action." 184 The Court concluded that permitting the state to regulate flag burning on the basis of mere speculation would amount to sanctioning state regulation of protected speech, a proposition that is deeply at odds with the First Amendment's core values. ${ }^{185}$

Finally, the Court noted that if Texas needed to guard against imminent violence, it already had a statute on the books governing breaches of the peace. ${ }^{186} \mathrm{In}$ view of the existence of such a statute and given the fact that disturbances did not actually occur in reaction to the defendant's speech, Texas's claim that the flag burning statute was necessary to prevent disturbances of the peace could not be believed.

The State's second justification-preservation of the flag as a symbol of

176. Tex. Penal Code Ann. $§ 42.09$ (a)(3) (1988).

177. Johnson, 491 U.S. at 399-400.

178. Id. at 407.

179. See id.

180. Id. at 408 .

181. See id. at $408-09$.

182. Id. at 409.

183. Id. at 408-09 (citing Terminiello v. Chicago, 337 U.S. 1, 4 (1949)).

184. Id. at 409 (citing Brandenburg v. Ohio, 395 U.S. 444, 447 (1969)).

185. See id. at 408-09.

186. Id. at 410 . 
national unity-received a different, though no better, treatment from the Court. The Court accepted the State's argument that the statute was necessary for the preservation of the flag as a symbol of nationhood. However, the Court concluded that this justification is content-based and insufficiently compelling to survive the Court's "most exacting scrutiny." ${ }^{\text {"187 }}$ The Texas statute was contentbased because whether the defendant violated the statute depended upon "the likely communicative impact of his expressive conduct." ${ }^{88}$ Only flag burnings that communicated a message inimical to the conception of the flag as a symbol of national unity violated the statute. ${ }^{189}$

Additionally, and perhaps more importantly, the statute is unconstitutional because it is a species of viewpoint discrimination. As the Court noted:

The state's argument is not that it has an interest simply in maintaining the flag as a symbol of something, no matter what is symbolizes; indeed, if that were the State's position, it would be difficult to see how that interest is endangered by highly symbolic conduct such as Johnson's. Rather, the State's claim is that it has an interest in preserving the flag as a symbol of nationhood and national unity, a symbol with a determinate range of meanings. According to Texas, if one physically treats the flag in a way that would tend to cast doubt on either the idea that nationhood and national unity are the flag's referents or that national unity actually exists, the message conveyed thereby is a harmful one and therefore may be prohibited. ${ }^{190}$

The state proscribed flag burning simply to prevent the defendant (and others like him) from using the flag as a means of communicating his socio-political dissatisfaction. ${ }^{191}$ The First Amendment does not permit the state to "forbid flag burning wherever it is likely to endanger the flag's symbolic role, but allow it wherever burning a flag promotes that role." 192 The Court concluded that the state cannot "criminally punish a person for burning the flag as a means of political protest." 193

As Professor Amar has noted, Texas v. Johnson is "plainly right, and even easy-indeed, as right and easy a case [as exists] in modern constitutional law." 194 Once one concedes that flag burning is protected speech, the case is easy and right because the state's illegitimate justification becomes apparent. When an individual burns a flag, the individual is almost invariably communicat-

187. Id. at 412 .

188. Id. at 411.

189. Id. at 410 (noting that the statute regulates content because the statute is implicated only when "a person's treatment of the flag communicates some expression").

190. Id. at 413 .

191. See id. at 411 ("[The] law is ... not aimed at protecting the physical integrity of the flag in all circumstances, but is designed instead to protect it only against impairments that would cause serious offense to others.").

192. Id. at 416.

193. Id. at 418 .

194. Amar, supra note 12 , at 125. 
ing a socio-political message, which is unquestionably protected under the First Amendment. Correspondingly, when the state promulgates legislation banning flag burning, the state can only be concerned with the message communicated by the incident. Thus, as soon as one eliminates the argument that flag burning is special and thus ought to be treated like obscenity or fighting words, the government's justification is not entitled to any deference. That is, once there is no longer a factual dispute about how flag burning affects the body politic, the state cannot demand deference to its view.

Consider next United States v. Eichman, ${ }^{195}$ decided the term following Johnson. In Eichman, the Court struck down a federal anti-flag burning statute on the ground that the statute violated the First Amendment. ${ }^{196}$ The statute provided that:

Whoever knowingly mutilates, defaces, physically defiles, burns, maintains on the floor or ground, or tramples upon any flag of the United States shall be fined under this title or imprisoned for not more than one year, or both.

This subsection does not prohibit any conduct consisting of the disposal of a flag when it has become worn or soiled. ${ }^{197}$

The government attempted to justify the statute on two grounds. First, the government argued that the Court should reconsider its decision in Johnson and hold that flag burning "does not enjoy the full protection of the First Amendment." 198 The Court unceremoniously rejected that argument. ${ }^{199}$ Second, the government argued that, unlike Texas's statute, this federal statute is contentneutral. ${ }^{200}$ The government explained that the Texas statute was unconstitutional because it prohibited flag burning only when burning the flag would seriously offend a spectator. ${ }^{201}$ In contrast, the federal statute did not contain any such limitations. It sought to "protect the physical integrity of the flag under all circumstances ... without regard to the actor's motive, his intended message, or to the likely effects of his conduct on onlookers." ${ }^{202}$ The Court also summarily disposed of this argument. ${ }^{203}$

The Court concluded that even without the telltale markers of speech infringement that were present in Johnson, the statute reflected the government's intent to regulate protected speech. ${ }^{204}$ Though the statute did not evidence an "explicit

195. 496 U.S. 310 (1990).

196. See id. The statute was passed by Congress in response to the Court's decision in Johnson.

197. 18 U.S.C. $\$ 700$ (1988 \& Supp. I 1989).

198. See Eichman, 496 U.S. at 315.

199. Id.

200. See id.

201. See Id.

202. Id.

203. See id.

204. See id. at 315-16. 
content-based limitation on the scope of prohibited conduct,"205 the Court nevertheless concluded that it is "clear that the Government's asserted interest" in promulgating the statute can be justified only on the basis of the content of the speech. ${ }^{206}$ Because the government did not offer any legitimate justifications for the statute, speech infringement is the only reasonable explanation for its passage. ${ }^{207}$

In addition, the Court also commented on the words chosen by Congress to delineate the scope of the statute's prohibition. The Court concluded that those words-mutilate, deface, defile, trample, and perhaps even burn-connoted "disrespectful treatment of the flag and suggest[ed] a focus on those acts likely to damage the flag's symbolic value."208 Similarly, the statutory exemption for activities associated with proper disposal of, and respect for, the flag removed all doubts that the statute was related to the suppression of speech. ${ }^{209}$

Johnson and Eichman demonstrate the ease with which one can dispose of state justifications for speech infringement when the state cannot regulate on the basis of a permissible criterion. Flag burning can reasonably communicate one message: social or political dissatisfaction. Because flag burning does not communicate multiple messages that differ in their constitutionality, there is no need to smoke out the state's illegitimate justification. Consequently, flag burning does not present an epistemic dilemma because there is no need to choose among competing justifications. ${ }^{210}$

Statutes regulating flag burning are not entitled to any deference; therefore, they are per se unconstitutional. Thus flag burning legislation, instead of engendering indecision or an epistemic impasse, gives rise to deep judicial skepticism.

In contrast to flag burnings, cross burnings may simultaneously communicate two types of messages of different constitutional standing: true threats and white supremacy. Whether one believes that statutes targeting cross burnings are per se unconstitutional depends upon whether one trusts that the government is acting in order to address a genuine harm or whether one believes the government is using the statute as a guise for message suppression. Supporters of statutes regulating cross burning often emphasize the harm caused by such conduct and the necessity of regulation. ${ }^{211}$ They argue that race-based hate

205. Id. at 315 .

206. Id.

207. See id. at 316.

208. Id. at 317 .

209. See id. at $317-18$.

210. Or put differently, to the extent that one believes the state's justification, the justification would not be consistent with the First Amendment.

211. See, e.g., R.A.V. v. City of St. Paul, 505 U.S. 377, 416 (1992) (Stevens, J., concurring) ("Conduct that creates special risks or causes special harms may be prohibited by special rules."); see also id. at 424 (Stevens, J., concurring) (noting that the "judgment ... that harms caused by racial, religious, and gender-based invective are qualitatively different from that caused by other fighting words ... seems ... eminently reasonable and realistic"); see also Robert C. Post, Racist Speech, 
activity is different from other types of speech-based conduct that are protected by the First Amendment. ${ }^{21 \dot{2}}$ In addition, they argue that First Amendment doctrine is sufficiently capacious to accommodate legislation regulating hatebased activity. ${ }^{213}$ Thus, for supporters of such legislation, while these statutes might violate the constitution on overbreadth grounds, they are not per se unconstitutional. Moreover, because the statutes address an important harm, proponents are more likely to believe the government when it maintains that it is legislating on the basis of the harm and not on the basis of the protected messages that may also be communicated by hate-based activity. ${ }^{214}$

Opponents of statutes that regulate hate-based activity tend to disbelieve the government when it claims that such regulations are not aimed at speech suppression. While opponents generally agree that activities like cross burning cause harm, they reject the contention that the state should "treat racial hate speech differently from other forms of hate-filled expression." ${ }^{215}$ Whereas proponents of hate speech legislation focus on the harm caused by such speech, opponents of hate speech statutes are motivated by the worry that the state is attempting to promote a politically correct viewpoint-for example racial tolerance-while at the same time suppressing a political viewpoint that it deems harmful to the body politic-for example speech that denigrates on the basis of race. ${ }^{216}$ For opponents of statutes regulating cross burning, state actors cannot single out cross burning for regulation without violating the First Amendment.

However, because cross burnings often communicate both messages simultaneousily, and because those messages are interrelated, it is difficult to discern whether the state is regulating on the basis of a permissible or impermissible

Democracy, and the First Amendment, 32 WM. \& MARY L. Rev. 267, 290-325 (1991) (summarizing arguments).

212. See, e.g., David Kretzmer, Freedom of Speech and Racism, 8 CARDozo L. Rev. 445, 458 (1987) (" $[R]$ acism is unique. This uniqueness is not of itsèlf a sufficient argument for restricting racist speech. It does, however, reveal why a discrete argument for restricting such speech may be made which does not apply to all other doctrines or ideas that may be considered offensive or dangerous."); Charles $\mathbf{R}$. Lawrence III, If He Hollers Let Him Go: Regulating Racist Speech On Campus, 1990 DukE L.J. 431, 459 ("To engage in a debate about the first amendment and racist speech without a full understanding of the nature and extent of the harm of racist speech risks making the first amendment an instrument of domination rather than a vehicle of liberation.").

213. See, e.g., Mari J. Matsuda, Legal Storytelling: Public Response to Racist Speech: Considering the Victim's Story, 87 Mich. L. Rev. 2320, 2356-61 (1989) (arguing that a sufficiently explicit and narrow definition of racist hate messages can allow for their restriction in a manner consistent with the First Amendment); Lawrence, supra note 212, at 449-57 (arguing that instances of racist speech are functionally equivalent to fighting words).

214. See, e.g., Mari J. Matsuda \& Charles R. Lawrence III, Epilogue: Burning Crosses and the R.A.V. Case, in Mari Matsuda et al., Words That Wound: Critical Race Theory, Assaultive Speech, AND THE First AMENDMENT 133, 135 (1993) ("Hate crime ordinances came about not because local legislators were bent on oppressing a tiny minority of unpopular racists, but because hate crimes had reached such an epidemic proportion that no one concerned with keeping the peace could ignore them.").

215. See Amar, supra note 12, at 125-26.

216. Steven G. Gey, The Case Against Postmodem Censorship Theory, 145 U. PA. L. REv. 193, 204 (1996). 
criterion. In this respect, courts are always operating at an epistemic disadvantage. They do not really know whether a state's justification is legitimate vel non. This prevents courts from determining with ease or confidence whether they should believe or doubt the state's justification-hence, the epistemic dilemma. How to resolve this epistemic dilemma is the fundamental question in R.A.V.

This epistemic dilemma is necessarily a question of trust, and therefore epistemic deference; or distrust, and thus epistemic skepticism. Correspondingly, where one draws the line depends upon the type of error that one finds tolerable. A constitutional posture that legitimates statutes that proscribe cross burnings risks an environment that undermines speech and facilitates government suppression of speech. Conversely, a constitutional posture that is hostile to cross-burning statutes risks an environment in which the government's attempt to address a genuine harm is frustrated by an unnecessarily restrictive constitutional doctrine. ${ }^{217}$

The constitutionality of statutes targeting cross burning therefore depends in great part on whether one is inclined to believe that cross burnings present a special type of harm; whether one believes that the state is regulating pursuant to that harm; and whether the state has alternative means at its disposal for addressing the putative harm caused by cross burnings. The absence of those three elements results in an almost absolute rejection of the constitutionality of cross burning statutes.

$R . A . V$. is best explained precisely along these lines. Justice Scalia and the R.A.V. majority were convinced that cross burnings do not present a distinctive harm. Moreover, they were also certain that even if the harms caused by cross burnings were distinctive, the state was not regulating pursuant to that harm. If the Court in R.A.V. was correct in its assessment of the harm presented by cross burnings and the propensity of the state to regulate the message as opposed to the harm, it owed no deference to the state's justifications. In fact, the Court was entitled, as it did, to draw a near-absolutist line on statutes regulating cross burning. Thus, R.A.V. stands for the proposition that statutes regulating cross burning are virtually always unconstitutional. The majority's somewhat unconventional doctrinal approach represented its distrust of the state and its skepticism that the state is regulating a unique type of harm.

Justice Souter's position in Black very much tracked Justice Scalia's in $R . A . V$. Justice Souter, as did Justice Scalia before him, viewed the content limitation of the statute as a telltale sign of the state's intent to engage in suppression of a politically incorrect message. ${ }^{218}$ Justice Souter was also skepti-

217. See Frederick Schauer, Uncoupling Free Speech, 92 CoLum. L. Rev. 1321, 1351-55 (1992).

218. Compare R.A.V. v. City of St. Paul, 505 U.S. 377, 396 (1992) ("In fact the only interest distinctively served by the content limitation is that of displaying the city council's special hostility towards the particular biases singled out."), and id. at 392 ("St. Paul's brief aserts that a general 'fighting words' law would not meet the city's needs because only a content-specific measure can communicate to minority groups that the 'group hatred' aspect of such speech is not condoned by the 
cal of the state's ability to regulate cross burning on the basis of a permissible criterion. ${ }^{219}$

By contrast, the majority in Black attempted to walk a finer line. It endeavored to accommodate the perceived state interest, which it found credible, with its concern about speech suppression, as indicated by its (unconvincing) analysis of the prima facie provision of the statute..$^{220}$

\section{BLack Cannot Be Squared with R.A.V.}

If my reading of R.A.V. is correct, then Black cannot be squared with R.A.V., notwithstanding Justice $O^{\prime}$ Connor's protestations to the contrary. Justice O'Connor, speaking for the Court, first attempted to distinguish R.A.V. on the ground that the statute in R.A.V. singled out for protection the speech of certain favored categories, such as race and gender, whereas the Virginia statute did not create any preferred categories. ${ }^{221}$ She then went on to note that under the Virginia statute, it "does not matter whether an individual burns a cross with intent to intimidate because of the victim's race, gender, or religion, or because of the victim's 'political affiliation, union membership, or homosexuality."'222

This initial attempt to distinguish R.A.V. is thoroughly unpersuasive. While the Virginia statute prohibits an individual from burning a cross with intent to intimidate regardless of the victim's race, religion, gender, etc., it is no less a content-based distinction than the St. Paul ordinance at issue in R.A.V. Just as St. Paul singled out a favored category (race, gender, and religion), Virginia selected one content-based category-cross burnings that communicate a threatening message - and prohibited intimidation on the basis of that category. ${ }^{223}$

The difference between Virginia's statute and St. Paul's ordinance is the level of generality at which the respective statutes operate. Although Virginia's statute regulates more generally than does St. Paul's ordinance, both regulate

majority."), with Virginia v. Black, 538 U.S. 343, 386-87 (2003) (Souter, J., concurring in part and dissenting in part) ("It is difficult to conceive of an intimidation case that would be easier to prove than one with cross burning, assuming any circumstances suggesting intimidation are present. The provision, apparently so unnecessary to legitimate prosecution of intimidation, is therefore quite enough to raise the question whether Virginia's content-based statute seeks more than mere protection against a virulent form of intimidation.... [A] content-neutral statute banning intimidation would achieve the same object without singling out particular content.").

219. Black, 538 U.S. at 383 (Souter, J, concurring in part and dissenting in part) ("The cross may have been selected because of its special power to threaten, but it may also have been singled out because of disapproval of its message of white supremacy, either because a legislature thought white supremacy was a perncious doctrine or because it found that dramatic, public espousal of it was a civic embarrassment.").

220. For a persuasive refuation of the majority's analysis of the prima facie provision, see Justice Scalia's concurring opinion. Id. at 368-71 (Scalia, J., concurring in part and dissenting in part).

221. Black, 538 U.S. at $361-62$

222. Id. at 362 .

223. See, e.g., id. at 381 (Souter, J., dissenting in part and concurring in part) ("Although the Virginia statute in issue here contains no such express 'basis of' limitation on prohibited subject matter, the specific prohibition of cross burning with intent to intimidate selects a symbol with particular content from the field of all proscribable expression meant to intimidate."). 
content. Consequently, they cannot be convincingly distinguished on the ground that the ordinance "discriminated on the basis of content by targeting only those individuals who 'provoke violence' on [the] basis [of race, color, creed, religion or gender]." ${ }^{324}$ Virginia's statute targets individuals who use crosses as a basis of intimidation. Thus, the regulations are analogous and one must conclude that they are equally content-based. ${ }^{225}$

The majority's second attempt is more promising, at least at first blush. It recognizes that an anti-cross-burning statute is a content-based regulation and attempts to fit cross-burning regulations within one of the exceptions delineated in R.A.V. The Court remarked that the "First Amendment permits Virginia to outlaw cross burnings done with the intent to intimidate because burning a cross is a particularly virulent form of intimidation."226 In light of "cross burning's long and pernicious history as a signal of impending violence," Virginia may choose to regulate cross burning as a type of intimidation that is "most likely to inspire fear and bodily harm."227

The majority found that Virginia's prohibition on cross burnings is saved through R.A.V.'s primary effects exception: the state may engage in contentbased regulation within a prohibited category when the state is regulating on the basis of the prohibited category's primary effects. ${ }^{228}$ Thus, a "ban on cross burning carried out with intent to intimidate is fully consistent with our holding in R.A.V. and is proscribable under the First Amendment."229 Accordingly, the state may prohibit cross burnings when the perpetrator's intent is to intimidate the victim.

This view would be plausible if it did not contradict R.A.V.'s holding and analysis. On the basis of Justice O'Connor's reasoning in Black, Justice Scalia should have similarly applied the primary effects exception to the St. Paul ordinance. If Virginia can permissibly regulate cross burning because Virginia is regulating "a particularly virulent form of intimidation," one could argue that St. Paul should have been able to single out fighting words uttered on the basis of race, gender, and religion because such fighting words are likely to cause anger and incite immediate violence. Notably, the Constitution is not neutral with respect to discrimination on the basis of racial, gender, and religious identity; it demonstrates a clear commitment to racial, gender, and religious equality. If cross burning itself is a particularly virulent type of intimidation,

224. Id. at 361 .

225. One could argue that the Court objected in R.A.V. to the fact that race was singled out as a basis for regulation. Cf. Shaw v. Reno, 509 U.S. 630 (1993) (holding that bizarre, race-based-and only bizarre, race-based-districting may violate the Fourteenth Amendment). That argument, as odd as it may be, would probably square Black with $R . A$.V. However, that is not the argument that the majority in Black advanced. It argued that $R . A$.V. objected to content-based distinctions as a general matter, not content-based distinctions on the basis of race. Black, 538 U.S. at 561-63.

226. Black, 538 U.S. at 363.

227. Id.

228. R.A.V. v. City of St. Paul, 505 U.S. 377, 388 (1992).

229. Black, 538 U.S. at 363. 
then burning a cross on the basis of the victim's race must certainly be an even more virulent type of intimidation. On the basis of this reasoning, R.A.V. is a stronger case than Black. That is, if one were to apply Black's reasoning to R.A.V., not only should the Court have upheld St. Paul's ordinance, but the ordinance presented a more compelling case for affirmance than the statute in Black.

However, Justice Scalia explicitly rejected this reasoning in $R . A . V .^{230}$ Indeed, Justice White, in his concurring opinion in R.A.V., took the majority to task on the basis of precisely this logic. As Justice White noted:

The ordinance proscribes a subset of "fighting words," those that injure "on the basis of race, color, creed, religion or gender." This selective regulation reflects the city's judgment that harms based on race, color, creed, religion, or gender are more pressing public concerns than the harms caused by other fighting words. In light of our Nation's long and painful experience with discrimination, this determination is plainly reasonable. Indeed, as the majority concedes, the interest is compelling. ${ }^{231}$

Thus, if the R.A.V. Court had followed Black's reasoning, it would have upheld the constitutionality of the St. Paul ordinance. Since R.A.V. foreclosed that line of argument, however, Justice O'Connor's attempt to distinguish Black from R.A.V. pursuant to the primary effects exception must fail. If Black comes under the primary effects exception, so does $R . A . V$., and both regulations are constitutional.

One can also apply Justice Scalia's reasoning in R.A.V. to strike down the statute in Black. Recall that in R.A.V., the St. Paul ordinance did not come within the scope of the primary effects exception because St. Paul did not regulate a particular "mode of expression" but sought to shape the content of public discourse. ${ }^{232}$ It is unclear how the Court arrived at the conclusion that the St. Paul ordinance reflected the city's intent to suppress speech, but it seemed to place a lot of weight on the city's belief that cross burnings were particularly harmful to its citizens of color, and the city's desire to communicate to its citizens of color that the city did not condone racist and white supremacist speech. In particular, the Court seemed to have deduced the city's illicit intent primarily from the fact that the city singled out cross burnings for special treatment. ${ }^{233}$ As the Court explained, the city wanted to single out cross burnings for special treatment so that it could express its "special hostility" for

230. R.A.V., 505 U.S. at 393 ("St. Paul has not singled out an especially offensive mode of expression - it has not, for example, selected for prohibition only those fighting words that communicate ideas in a threatening (as opposed to a merely obnoxious) manner."); see supra text accompanying note 94.

231. Id. at 407 (White, J., concurring in judgment).

232. Id. at 393-94.

233. Id. at $393,396$. 
the message communicated by cross burnings. ${ }^{234}$ This observation, coupled with St. Paul's protection of ostensibly politically correct categories-race, gender, and religion-led the Court to conclude that St. Paul objected to the message communicated by cross burnings as opposed to the legitimate harms suffered by the victims of cross burnings. ${ }^{235}$

Given that the St. Paul ordinance cannot be saved by any of the exceptions to content-based distinctions, the statute could only survive if it is narrowly tailored to serve a compelling state interest. ${ }^{236}$ The Court in R.A.V. conceded that the ordinance served a compelling state interest, to "ensure the basic human rights of members of groups that have historically been subjected to discrimination,"237 but it was not sufficiently narrowly tailored. The city could have enacted a more general ordinance if it really wanted to prevent perpetrators from burning crosses in other people's front yards. The city had "sufficient means at its disposal to prevent such behavior[s] without adding the First Amendment to the fire." 238 This reasoning can also be applied to the statute in Black.

In fact, Justice Souter advanced a similar argument in Black. According to Justice Souter, the primary effects exception applies only when a statute regulates speech "'entirely' on the 'basis' of 'the very reason' that 'the entire class of speech at issue is proscribable' at all."239 Justice Souter argued that contrary to the majority's assertion, Virginia's cross-burning statute was not saved by the primary effects exception because the statute defined a content-based subclasscross burnings - on the basis of the particular message communicated by the subclass. ${ }^{240}$ Justice Souter argued that the cross is a symbol that can communicate multiple messages and thus cannot be regulated entirely on the basis of its

234. Id. at 396.

235. Justice Scalia purports to derive from the Minnesota Supreme Court's opinion upholding the statute, and the city's brief before the United States Supreme Court supporting the statute, the idea that the ordinance is necessary to communicate to the city's citizens of color that the majority disapproves of the message that cross burning communicates. $I d$. at 392. But the quoted passage does a disservice to the Minnesota Supreme Court's opinion and to the city's statement of the ordinance's purpose. While one may argue that the Minnesota Supreme Court was unsuccessful in its attempt to save the statute, it is difficult to maintain that that court viewed the statute as an attempt to suppress ideas based upon white supremacy as opposed to an attempt to suppress violence that is motivated by white supremacist ideals. See In re R.A.V., 464 N.W.2d 507, 510-11 (Minn. 1991), rev'd sub. nom. R.A.V. v. City of St. Paul, 505 U.S. 577 (1992) (reflecting the Court's attempt to limit the ordinance to conduct that "inflicts injury" or incites imminent lawless action). Similarly, a more accurate statement is the city's contention in its brief that "the Ordinance is intended not to impact the right of free expression of the accused but rather to protect against the victimization of a person or persons who are particularly vulnerable because of their membership in a group that historically has been discriminated against." Respondent's Brief at 28, R.A.V. v. City of St. Paul, 505 U.S. 377 (1992) (No. 90-7675).

236. R.A.V., 505 U.S. at 395.

237. Id.

238. Id. at 396.

239. Virginia v. Black, 538 U.S. 343, 381 (2003) (Souter, J., concurring in the judgment in part and dissenting in part).

240. Id. at 381-82. 
putative primary effect. ${ }^{241}$ As he explained:

The cross may have been selected because of its special power to threaten, but it may also have been singled out because of disapproval of its message of white supremacy, either because a legislature thought white supremacy was a pernicious doctrine or because it found that dramatic, public espousal of it was a civic embarrassment....

... A content-based proscription of cross burning . . . may be a subtle effort to ban not only the intensity of the intimidation cross burning causes when done to threaten, but also the particular message of white supremacy that is broadcast even by nonthreatening cross burning. ${ }^{242}$

Some of these messages are constitutionally protected-for example, messages based upon ideology. Others are not-such as messages that fall under the category of true threats. Further, when one combines the prima facie intent provision with the expressive message communicated by cross burnings, the primary effects rationale is untenable as a basis of constitutionality. ${ }^{243}$

Justice Souter's opinion demonstrates the applicability of R.A.V. to Black. Thus, irrespective of one's view of the constitutionality of Black and R.A.V., these are similar cases that cannot be easily distinguished. Black's similarity to R.A.V. becomes all the more inescapable if one gives effect to R.A.V.'s viewpoint discrimination prong. Recall Justice Scalia's admonition that the state could not "license one side of a debate to fight freestyle, while requiring the other to follow Marquis of Queensberry rules."244 One could argue that cross burning is the most potent arrow in the white supremacist's quiver. ${ }^{245}$ Those who wish to deliver a message of racial harmony are extremely unlikely to use cross burning as their mode of communication. Consequently, when the state regulates cross burning, it is undoubtedly handicapping one side of the debate.

Thus, Black's facile conclusion that "[a] ban on cross burning carried out with the intent to intimidate is fully consistent with ...R.A.V."246 is fully unsound. If the statute in R.A.V. is unconstitutional, so is the one in Black. Conversely, if Black is correct, then the Court was wrong in R.A.V. In any event, Black cannot be squared with R.A.V. As Professor Schauer has aptly concluded, "there exist two mutually exclusive precedents with no clear indication that the latter supercedes the former." ${ }^{247}$

241. Id. at 382-84.

242. Id. at 383-84.

243. See id. at 382-85.

244. R.A.V. v. City of St. Paul, 505 U.S. 377, 392 (1992).

245. In fact, the Court's review of the history of cross burning in the United States proves as much. See Black, 538 U.S. at 352-57.

246. Black, 538 U.S. at 363.

247. Schauer, supra note 134, at 209. 


\section{Justice Thomas's Contribution}

\section{A. JUSTICE THOMAS'S VIEWS ON CROSS BURNING}

If $R . A . V$. is properly interpreted as prohibiting state statutes that single out cross burnings for regulation, what accounts for the Court's decision in Black? To understand why R.A.V. and Black come out so differently, one must come to grips with the role that Justice Thomas played in Black. Anyone who listened to or witnessed the Supreme Court oral arguments in Black could not help but be struck by the manner in which Justice Thomas's comments on the meaning of cross burnings single-handedly changed the nature of the proceedings. ${ }^{248}$ What is most remarkable about Justice Thomas's participation in Black (other than the fact that he spoke out at all), especially when considered in contrast to his participation in R.A.V., in which he joined Justice Scalia's majority opinion, is that Justice Thomas analyzed the harm caused by cross burning from his perspective as a person of color. ${ }^{249}$ Justice Thomas brought sensitivity to the issue that he had acquired on the basis of his experiences as an African American. ${ }^{250}$

Examine this remarkable exchange during oral argument in Black, which occurred while the Deputy Solicitor General of the Department of Justice was arguing in favor of the constitutionality of the Virginia statute:

[Justice Thomas]: Mr. Dreeben, aren't you understating the-the effects of- of the burning cross?

[Justice Thomas]: Now it's my understanding that we had almost 100 years of lynching and activity in the South by the Knights of Camellia and-and the $\mathrm{Ku}$ Klux Klan, and this was a reign of terror and the cross was a symbol of

248. Dahlia Lithwick, Opinion-Editorial, Personal Truths and Legal Fictions, N.Y. TMMEs, Dec. 17, 2002, at A35 (stating that Justice Thomas's "words changed the tenor of the debate, if not the minds of his colleagues, about the role of the law and the definition of justice"); see also Erwin Chemerinsky, Striking a Balance on Hate Speech, 39 TRIAL 78 (2003).

249. For a broader discussion of the voice of color, see Robert S. Chang, Toward An Asian American Legal Scholarship: Critical Race Theory, Post-Structuralism, and Narrative Space, 81 CAL. L. REv. 1241, 1268-71 (1993); Alex M. Johnson, Jr., Defending the Use of Narrative and Giving Content to the Voice of Color: Rejecting the Imposition of Process Theory in Legal Scholarship, 79 Iowa L. Rev. 803, 830-42 (1994); and Alex M. Johnson, Jr., The New Voice of Color, 100 YALE L.J. 2007, 2043-52 (1991). For a skeptical view, see Daniel A. Farber \& Suzanna Sherry, Telling Stories Out of School, 45 Stan. L. Rev. 807, 809 (1993).

250. It is not clear to me why Justice Thomas joined Justice Scalia in R.A.V. without writing or speaking, but dissented so vigorously in Black. One can surmise that perhaps as a new member of the Court, Justice Thomas did not want to make waves. (R.A.V. was argued in December of the 1991 term, Thomas's first on the Court.) Or perhaps Justice Thomas concluded that his confirmation battles, framed by race, would have undermined his credibility to speak on behalf of citizens of color. Or perhaps he only later came to terms with the meaning of cross burning or the ability to reconcile statutes that prohibit cross burning with the First Amendment. Or perhaps this is Justice Thomas's way of reaching out to the civil rights community. These are all hypotheses; I am not clear as to what changed for Justice Thomas between R.A.V. and Black. 
that reign of terror. Was-isn't that significantly greater than intimidation or a threat?

Answer: Well, I think they're coextensive, Justice Thomas, because it is-

[Justice Thomas]: Well, my fear is, Mr. Dreeben, that you're actually understating the symbolism on-of and the effect of the cross, the burning cross. I-I indicated, I think, in the Ohio case that the cross was not a religious symbol and that it has-it was intended to have a virulent effect. And I-I think that what you're attempting to do is to fit this into our jurisprudence rather than stating more clearly what the cross was intended to accomplish and, indeed, that is unlike any symbol in our society ....

...

... [M]y fear is that the-there was no other purpose to the cross. There was no communication of a particular message. It was intended to cause fear $\ldots$ and to terrorize a population. ${ }^{251}$

Justice Thomas expanded further on this theme in his dissent in Black. He adopted a voice of color at the very beginning of his dissent. He began by noting that in "every culture, certain things acquire meaning well beyond what outsiders can comprehend."252 Quoting from a Ninth Circuit case, he explained that to African-Americans cross burnings signify: "[m]urder, hanging, rape, lynching. Just about anything bad that you can name. It is the worst thing that can happen to a person." 253 He provides a short history of cross burnings in the United States and then proceeds to explain that the burning cross has and can only have one meaning: an intent to intimidate. ${ }^{254}$

In that regard, his analysis does not differ much from that of the majority. But the lesson that he derives from his historical overview has wider doctrinal implications than that of the majority. On the basis of this history, he concludes that " $[i] \mathrm{n}$ our culture, cross burning has almost invariably meant lawlessness and understandably instills in its victims well-grounded fear of physical vio-

251. Transcript of Oral Argument at 22-24, Virginia v. Black, 538 U.S. 343 (2003) (No. 01-1107) [hereinafter Transcript].

252. Black, 538 U.S. at 388 (Thomas, J., dissenting). Now, one could question what it is that he means by "outsiders." Does he mean non-Americans? Whites? Americans who are not of African descent? I think he means all three. Justice Thomas's opinion is careful to promote a sort of racial ecumenism. Cross burning is a tool that is used to intimidate African-Americans, but it is not limited to African-Americans. Justice Thomas explains that "the perception that a burning cross is a threat and a precursor of worse things to come is not limited to blacks [b]ecause the modern Klan expanded the list of its enemies beyond blacks and 'radicals,' to include Catholics, Jews, most immigrants, and labor unions." Id. at 1564. Thus, "our culture" begins with African-Americans, but is soon expanded to include all Americans. Of course this move is a bit disingenuous. That Justice Thomas finds it necessary to explain "our culture" to some of us is indicative of the fact that we do not share the same culture, or at least that we do not share it in the same way. Justice Thomas's comments during oral argument and his dissent derive their power from the realization that his culture does not overlap perfectly with the culture of his colleagues. We are not all equally likely to understand the harm caused by cross burning because we do not all share the same culture.

253. Black, 538 U.S. at 390 (Thomas, J., dissenting) (quoting United States v. Skillman, 922 F.2d 1370,1378 (9th Cir. 1991).

254. Black, 538 U.S. at $392-93$. 
lence."255 Consequently, a ban on cross burnings carried out with an intent to intimidate prohibits conduct only; it does not limit any constitutionally protected expression. He also reviews Virginia's experience with cross burning and concludes that the purpose of the Virginia statute is not to limit racist speech, but to deter the Klan's terroristic activities. ${ }^{256}$ Moreover, he maintains that the prima facie provision constitutes a rebuttable presumption and therefore does not raise any problems under the First Amendment. ${ }^{257}$

\section{B. JUSTICE THOMAS: EPISTEMIC AUTHORITY AND EPISTEMIC DEFERENCE}

Justice Thomas's comments during oral argument in Black are noteworthy both because he rarely asks questions during oral arguments and because of the impact those comments had on his colleagues. By all accounts, Justice Thomas's statements appeared to have a tremendous effect on his fellow Justices. ${ }^{258}$ One cannot help but believe that Justice Thomas's active participation, including his dissent as well as his statements during oral argument, best explains the Court's decision to turn away from the absolutist position of R.A.V. to the more flexible and nuanced approach reflected in Black. Thus, while Justice Thomas's position did not ultimately prevail in Black, it certainly framed the disposition of the case.

To understand how Justice Thomas may have contributed to the resolution of this case, one must begin with the philosophical concept of epistemic authority. Generally speaking, epistemic authority is invoked when one accepts a factual assertion as true because someone else-someone with epistemic authoritysays that it is true. ${ }^{259}$ Epistemic authority is an analytical tool used to resolve uncertainty. Determining whether a person is entitled to epistemic deference, on the basis of his or her epistemic authority, requires that one navigate through a series of inquiries with respect to who should be believed, under what circumstances, and with respect to what issues. ${ }^{260}$ As political and legal philosopher Don Herzog remarks, epistemic authority and epistemic deference are always

255. Id. at 391 .

256. Id. at 394.

257. Id. at 398.

258. Linda Greenhouse, An Intense Attack by Justice Thomas on Cross-Burning, N.Y. TimEs, Dec. 12,2002 , at $\mathrm{A} 1$ ("The case, concerning a 50-year-old Virginia law, raised tricky questions of First Amendment doctrine, and it was not clear how the court was inclined to decide it-until Justice Clarence Thomas spoke."); see also Charles Lane, High Court Hears Thomas on KKK Rite: Justice Weighs In on Va. Cross-Burning Ban, WASH. Post, Dec. 12, 2002, at Al ("The debate's emotional high point was provided by the usually taciturn Justice Clarence Thomas.").

259. See, e.g., Richard T. De George, The Function and Limits of Epistemic Authority, 8 S.J. Pm. 199 (1970) ("Epistemic authority is authority which is based on knowledge."); see also Don HERzoG, Poisoning the Minds of the Lower Orders 156 (1998); Richard T. De George, The Nature and Function of Epistemic Authority, in AuthorITY: A PHLLosophicAl ANAlysis 79-80 (R. Baine Harris ed., 1976). For other useful discussions of epistemic authority, see JOSEPH RAZ, THE MoRALITY of FreEdom 38-69 (1986); Scott Brewer, Scientific Expert Testimony and Intellectual Due Process, 107 YALE L.J. 1535, 1586-96 (1998); Heidi M. Hurd, Challenging Authority, 100 YaLE L.J. 1611 (1991).

260. Don Herzog, Up from Individualism, 86 CAL. L. Rev, 459, 465 (1998) 
part of the conversation. ${ }^{261}$

As a matter of brute fact, we are hugely and irrevocably dependent on others for what we know. I believe the Soviet Union fell in 1989 because I read about it in the newspapers: that is, because other people told me. "But you saw a bit of it, with your own eyes, on TV!" That is, I saw scenes that other people told me were the fall of the Soviet Union. "You could fly there yourself!" That is, I could get on a plane and fly to a place that others would tell me is Russia and the people there would tell me about what happened in 1989. ${ }^{262}$

Fundamentally, what we know depends upon whom we believe (and vice versa). Whom we believe is a question of epistemic authority.

Statutes prohibiting cross burnings present courts with an epistemic problem: is the state regulating cross burning because of its politically unpalatable message or because cross burnings cause special harms? To the extent that one believes that cross burnings, and hate speech more generally, cause a unique kind of harm, one would be more inclined to conclude that anti-cross-burning statutes are constitutional. Conversely, to the extent that one believes that cross burnings are similar to other types of prohibited conduct, one would be more inclined to believe that statutes specifically targeting cross burnings for regulation are really not concerned with the harm that cross burnings cause but with the message that they communicate.

Remember that the majority in R.A.V. refused to defer to the views of the state. But Black is different. Why? Because Justice Thomas spoke up. Justice Thomas - an African-American colleague, a conservative, raised in the South, a victim of racism — possesses epistemic authority and commands epistemic deference. He alone on the Court is positioned to explain, on the basis of what he knows to be true and what he has experienced as a person of color, the distinctive harm caused by cross burnings from the perspective of one of its likely victims. When Justice Thomas maintains that the cross is unlike any other symbol in our society, he cannot be dismissed simply as a purveyor of political correctness, as were the critical race theorists and St. Paul in R.A.V., or ignored, as were the concurrences in R.A.V. His colleagues must acknowledge his contentions. Justice Thomas's participation in Black exemplifies how experience creates knowledge, and it is that experiential knowledge that forms the basis for his epistemic authority. ${ }^{263}$

As soon as one defers to Justice Thomas on the question of harm, the burden shifts to the skeptic to explain why the First Amendment cannot accommodate a narrowly drawn cross-burning statute. Consider the following exchange be-

261. Id.

262. Id.

263. For an argument about the relationship between experience and knowledge, see PATRICIA J. Williams, The Alchemy of Race AND Rights 44-51, 166-78 (1991). 
tween Justice O'Connor and Dean Smolla, once again at oral argument:

[Dean] Smolla: -as-as powerful as that point is [that the purpose of cross burning is to terrorize] - and I totally accept it, and totally accept the history that Justice Thomas has--has recounted, and that the United States recounts in its brief as accurate. As powerful as all of those points are, there's not a single interest that society seeks to protect in protecting that victim that cannot be vindicated perfectly as well, exactly as well with no fall-off at all, by content-neutral alternatives, not merely general run-of-the-mill threat laws, or incitement laws, or intimidation laws which may have an antiseptic and sterile quality about them. You can go even beyond that-

[Justice O'Connor]: But why isn't this just a regulation of a particularly virulent form of intimidation? And why can't the State regulate such things?

[Dean] Smolla: Your Honor, it is not a particularly virulent form of intimidation.

[Justice O'Connor]: Well, it is for the very reasons we've explored this morning. What if I think it is? Why can't the State regulate it? ${ }^{264}$

Note that one cannot have it both ways. One must either accept Justice Thomas's account or reject it. Attempting to have it both ways, as Dean Smolla tried at oral argument, places one in the awkward position of arguing that even though as a matter of real-world historical fact the (sole) purpose of cross burning is to intimidate its victims, the state is nevertheless powerless to target cross burnings because of the First Amendment. The argument rings hollow, ${ }^{265}$ and Dean Smolla's otherwise perfectly acceptable argument-the availability of content-neutral alternatives, which prevailed in R.A.V.-no longer suffices. The content-neutral alternative is a winning argument only when the reviewing court is skeptical of the state's motives; it fails once the court agrees that the state is

264. Transcript, supra note 251, at 31 . Consider also the following colloquy:

Question: In other words, all it-all it-all you're saying is that heightened scrutiny applies.

[Dean] Smolla: We are certainly saying that, and-

Question: That's all you're saying. You can't possibly say more than that once you acknowledge that - that symbols can be proscribed.

[Dean] Smolla: We-we say that-

Question: And so the question before us whether burning a cross is such a terrorizing symbol in American-in American culture that even on the basis of heightened scrutiny, it's okay to proscribe it. That's basically the-

[Dean] Smolla: That is a-that is a fair characterization of the question.

Id. at 36-37.

265. The argument is similar to one advanced by Justice Holmes in Giles v. Harris, 189 U.S. 475 (1903). In Giles, African-American plaintiffs filed suit challenging Alabama's registration scheme on the ground that it was designed to disenfranchise that state's African-American voters. While Holmes, who wrote the Court's opinion in the case, agreed that the plaintiff had suffered "a great political wrong," he confessed impotence. Id. at 488. The Fifteenth Amendment notwithstanding, he maintained that the Court has "little practical power" to rectify that wrong. Id. For more on Giles, see Richard $\mathrm{H}$. Pildes, Democracy, Anti-Democracy and the Canon, 17 Const. Comment. 295 (2000). 
not engaged in speech suppression but is addressing an important harm. ${ }^{266}$ Having conceded that cross burnings cause a distinctive type of harm- "for the very reasons we've explored this morning," ${ }^{267}$ which means on the basis of Justice Thomas's testimony-the Court could not resist the allure of Justice O'Connor's question: Why can't the state regulate it? ${ }^{268}$

\section{THE CONTOURS OF EPISTEMIC AUTHORITY}

That Justice Thomas's epistemic authority is determinative in Black-that it affects the outcome-does not mean that it is determinative with respect to all issues involving race. In fact, Black is exceptional in part because it is one of Justice Thomas's few wins in this area. ${ }^{269}$ Some noteworthy losses include the recent Grutter v. Bollinger, challenging the University of Michigan Law School's affirmative action program; ${ }^{270}$ United States v. Fordice, addressing Mississippi's segregated state university system; ${ }^{271}$ Missouri v. Jenkins, a school desegregation case $;^{272}$ and City of Chicago v. Morales, which addressed the constitutionality of Chicago's anti-loitering ordinance. ${ }^{273}$

However, one should not conclude that because Justice Thomas's opinion on racial matters does not command deference across the board, epistemic authority was not a background dispute in any of those cases. It was. The fact that one may defer to the epistemic authority of someone in regard to one subject matter does not necessarily mean that one defers to her on all subject matters. Ascertaining the contexts, domains, or subject matters that command epistemic deference is part of the inquiry into epistemic authority. ${ }^{274}$

Consider Korematsu v. United States, ${ }^{275}$ the Japanese internment case, as one unrecognized example of a controversial appeal to epistemic authority. In Korematsu, the Supreme Court upheld the internment of Japanese Americans against a constitutional challenge, concluding that the order upon which the internment was based was not "beyond the war power of Congress and the Executive ...."276 The Court cited the need to defer to the greater expertise of military authorities as the primary justification for its decision. ${ }^{277}$ "The military authorities, charged with the primary responsibility of defending our shores,"

266. See Wisconsin v. Mitchell, 508 U.S. 476, 487-88 (1993).

267. Transcript, supra note 251 , at 31 .

268. Id.

269. One could probably count Zelman v. Simmons-Harris, 536 U.S. 639, 676 (2002) (Thomas, J., concurring), as a win.

270. 539 U.S. 306,349 (2003) (Thomas, J., concurring in part and dissenting in part).

271. 505 U.S. 717,745 (1992) (Thomas, J., concurring).

272. 515 U.S. 70, 114 (1995) (Thomas, J., concurring).

273. 527 U.S. 41,98 (1999) (Thomas, J., dissenting).

„274. Id. at 465 .

275. 323 U.S. 214 (1944), conviction vacated on writ of coram nobis, 584 F. Supp. 1406 (N.D. Cal. 1984).

276. Korematsu, 323 U.S. at 217.

277. Id. at 218-19. 
the Court stated, "concluded that curfew provided inadequate protection and ordered exclusion." 278 The military not only bears the responsibility for national defense, but it is also in the best position to assess risks. ${ }^{279}$ Thus, the Court explains:

[W] cannot reject as unfounded the judgment of the military authorities and of Congress that there were disloyal members of that population, whose number and strength could not be precisely and quickly ascertained. We cannot say that the war-making branches of the Government did not have ground for believing that in a critical hour such persons could not readily be isolated and separately dealt with, and constituted a menace to the national defense and safety ....280

Korematsu has been roundly criticized precisely because of the Court's decision to defer to the supposed greater expertise of the military. ${ }^{281}$

As Korematsu demonstrates, epistemic authority is often part, though frequently an unacknowledged part, of the discussion. However, Korematsu is deeply unsatisfying not simply because of the Court's decision, but also because of the Court's failure to address some important questions raised by its appeal to epistemic authority. ${ }^{282}$ When should the Court defer to the assertion of epistemic authority? What standards should the Court use in evaluating the merits of epistemic claims? Contrast the more helpful approach of Justice Jackson, dissenting in Korematsu. ${ }^{283}$

Justice Jackson advanced two arguments. First, he noted that the Court is not positioned to examine epistemic claims by military authorities. ${ }^{284}$ There are

\section{Id. at 218 .}

279. $I d$.

280. $I d$.

281. See, e.g., Reggie Oh \& Frank Wu, The Evolution of Race in the Law: The Supreme Court Moves From Approving Internment of Japanese Americans to Disapproving Affirmative Action for African Americans, 1 Mich. J. RACE \& L. 165, 169 (1996).

282. See, e.g., Korematsu, 323 U.S. at 242, 245 (Jackson, J., dissenting).

283. Justice Murphy's dissent is also instructive on the question of epistemic authority. Unlike the majority and Justice Jackson, Justice Murphy took issue with the factual assertions of the military officials and provided a framework for evaluating the military's assertion of epistemic deference. First, Justice Murphy argued that the factual bases for the internment are based "upon questionable racial and sociological grounds not ordinarily within the realm of expert military judgment." 323 U.S. at 236-37. Because military officers made decisions on grounds that were not within their area of expertise, the officers are not epistemic authorities with respect to those decisions. Consequently, those decisions are "not entitled to the great weight ordinarily given the judgments based upon strictly military considerations." Id. at 240 . Second, the Court does not owe the military complete deference even when military officials are operating in areas within their military expertise. The Court's role is to determine whether military action "is reasonably related to a public danger that is so immediate, imminent, and impending as not to admit of delay and not to permit the intervention of ordinary constitutional processes to alleviate the danger." Id. at 234 (internal quotation marks omitted); see also id. at 235 (stating that military action must have "some reasonable relation to the removal of, the dangers of invasion, sabotage and espionage").

284. See id. at 245. 
contexts in which the Court operates at an epistemic disadvantage-Justice Jackson used the term "limitation"-war is one of those contexts. ${ }^{285}$ There are certain facts that military officials know and that courts do not and cannot know. Moreover, courts rarely are capable of evaluating the reasonableness of military action. That is, courts cannot determine confidently that the facts as they are believed to exist by the military official do not so exist. ${ }^{286}$ I will characterize this claim as the realization that epistemic authority is context-dependent. Justice Jackson wrote:

In the very nature of things, military decisions are not susceptible of intelligent judicial appraisal. They do not pretend to rest on evidence, but are made on information that often would not be admissible and on assumptions that could not be proved. Information in support of an order could not be disclosed to courts without danger that it would reach the enemy. Neither can courts act on communications made in confidence. Hence courts can never have any real alternative to accepting the mere declaration of the authority that issued the order that it was reasonably necessary from a military viewpoint. ${ }^{287}$

On this score, Justice Jackson essentially agreed with the majority that one cannot second-guess military leaders in times of war. One must take their assertions as fact. But here the similarities end. Justice Jackson advanced a second argument. He suggested that although the Court was compelled to accept the military's factual assertions that internment was necessary, that acceptance did not lead ineluctably to the conclusion that the internment was constitutional. ${ }^{288}$ Epistemic deference did not extend to determination of the constitutional question.

From this perspective, epistemic authority is institution-dependent. The military has a role, to which courts ought to defer. ${ }^{289}$ But courts also have a role,

285. See id. at $244-45$.

286. Justice Jackson maintained:

The limitation under which courts always will labor in examining the necessity for a military order are illustrated by this case. How does the Court know that these orders have a reasonable basis in necessity? No evidence whatever on that subject has been taken by this or any other court. There is sharp controversy as to the credibility of the DeWitt report [the military report upon which the military order is based]. So the Court, having no real evidence before it, has no choice but to accept General DeWitt's own unsworn, self-serving statement, untested by any cross-examination, that what he did was reasonable. And thus it will always be when courts try to look into the reasonableness of a military order.

Id. at 245 .

287. Id.

288. Id. at 244 ("And it is said that if the military commander had reasonable military grounds for promulgating the orders, they are constitutional and become law, and the Court is required to enforce them. There are several reasons why I cannot subscribe to this doctrine."):

289. See id. ("The armed services must protect a society, not merely its Constitution. The very essence of the military job is to marshal physical force, to remove every obstacle to its effectiveness, to give it every strategic advantage."). 
and in fulfilling their task, they ought not defer to any other institution. The constitutional question is strictly a matter for judicial determination. ${ }^{290}$

Consider also the recent Grutter case. Part of the dispute in Grutter was whether the law school's assertion that diversity is a necessary part of its educational mission constitutes a compelling state interest. How should the Court have evaluated the law school's assertion that diversity is an integral part of its educational mission? Compare the following approaches.

In her opinion for the Court, Justice O'Connor stated that the law school's "educational judgment that ... diversity is essential to its educational mission is one to which we defer."291 Why? First and perhaps most importantly, because the law school said so and we "presume[" that the good administrators at the University of Michigan act on "good faith absent a showing to the contrary."292 This explanation is a classic account of epistemic authority: We defer to people who know more than we do-because of their institutional, professional, or experiential expertise-unless we have reason to believe that they do not know better. Second, the law school amassed an impressive array of witnesses who testified to that effect at trial and whose views were made part of the record for the Court to consider. ${ }^{293}$ Third, a phalanx of law schools, universities, educational establishments, scholars, and educators participated as amici in the case and chanted the same refrain. ${ }^{294}$ In addition, high-ranking retired officers and civilian leaders of the United States military testified to the importance of racial diversity. ${ }^{295}$ Lastly, major American businesses have made clear that the skills needed in today's increasingly global marketplace can be developed only through exposure to "widely diverse people, cultures, ideas, and viewpoints."296 Again, these are classic claims of epistemic authority-our military depends upon a diverse racial pool. Who are we to question them? In view of the nature, quality, and breadth of the authorities advancing the same claim before the Court, what is the Court to do?

Similarly, note that Justice O'Connor herself benefited from a brush with diversity. By her own account, Justice Marshall "profoundly influence[d]" her because he brought "a special perspective" to the Court. ${ }^{297}$ One cannot help but think about the Michigan cases when Justice O'Connor explains that Justice Marshall taught her and her colleagues that "the law is not an abstract concept

290. See id. at 247 "I should hold that a civil court cannot be made to enforce an order which violates constitutional limitations even if it is a reasonable exercise of military authority. The courts can exercise only the judicial power, can apply only law, and must abide by the Constitution, or they cease to be civil courts and become instruments of military policy.").

291. Grutter, 539 U.S. at 328.

292. Id. at 329.

293. See id. at 330 (noting the expert studies and reports entered into evidence at trial).

294. See id.

295. Id. at 331 .

296. Id. at 330 .

297. Sandra Day O'Connor, Thurgood Marshall: The Influence of a Raconteur, 44 STAN. L. REv. 1217,1217 (1992). 
removed from the society it serves, and that judges, as safeguarders of the Constitution, must constantly strive to narrow the gap between the ideal of equal justice and the reality of social inequality."298

Consider Justice O'Connor's opinion in contrast to Justice Thomas's approach in Grutter. On this score, Justice Thomas advanced two arguments. First, Justice Thomas argued that if Michigan really was interested in diversity, it would lower its academic standards and admit a diverse student body. ${ }^{299}$ Michigan's refusal to explore that strategy suggested that it was not really interested in diversity. ${ }^{300}$ Second, Justice Thomas maintained that to the extent that educational benefits flow from racial diversity, Michigan was using race to subsidize its educational quality, suggesting again that the law school was not really interested in diversity. Instead the law school was using "racial discrimination as a tool to advance [its] interest in offering a marginally superior education while maintaining itself as an elite institution." ${ }^{301}$ Thus, for Justice Thomas, the question is whether Michigan has a compelling interest in using race so that it may maintain its status as an elite law school. ${ }^{302}$ The answer, of course, is that elite status is not a compelling reason for racial classifications.

Note that while Justice Thomas decried the "unprecedented deference to the Law School-a deference antithetical to strict scrutiny," ${ }^{, 303}$ he too is handicapped by the law school's assertion. After all, is Justice Thomas better positioned than the administrators at the law school to ascertain whether educational benefits flow from a diverse student body? ${ }^{304}$ Further, how does one refute the law school's epistemic claim? Although Justice Thomas gestures weakly in the direction of social science evidence that contradicts the law school's assertion, ${ }^{305}$ he does not push the point very far. What is a Justice to do when the "cognoscenti" are impressively arrayed against him??

In a different vein, what should one make of Justice O'Connor's refusal to defer to the black city council members in City of Richmond v. Croson ${ }^{307}$ in comparison with her willingness to defer to the white administrators in Grutter? In Croson, the City of Richmond adopted a set-aside plan that required contractors who did business with the City to subcontract no less than $30 \%$ of the

298. Id. at 1218.

299. Grutter, 539 U.S. at 355-56 (Thomas, J., concurring in part and dissenting in part).

300. See id.

301. Id. at 356 .

302. Id. at 356-60.

303. Id. at 362 .

304. He did use the Internet to find empirical support for his point that Boalt Hall is doing just fine in the wake of Proposition 209, which barred California state universities from using race as a factor in admissions, id. at 367, and that "the Law School trains few Michigan residents and overwhelmingly serves students who, as lawyers, leave the State of Michigan," id. at 359-60.

305. See id. at 364 (noting "the growing evidence that racial (and other sorts) of heterogeneity actually impairs learning among black students").

306. See id. at 350 ("The majority upholds the Law School's racial discrimination not by interpreting the people's Constitution, but by responding to a faddish slogan of the cognoscenti.").

307. 488 U.S. 469 (1989). 
contract to at least one "Minority Business Enterprise." ${ }^{308}$ At the time, 50\% of the City's residents were Black ${ }^{309}$ and five of the nine city council members were Black. ${ }^{310}$ The City concluded that the set-aside plan was necessary to remedy discrimination in the construction industry. The Court disagreed.

What is it that accounts for the Court's failure to defer to the Richmond city council as it did to the University of Michigan Law School? Is this an instance of epistemic authority as context-dependent ${ }^{311}$ Is this an instance of epistemic authority as institution-dependent? ${ }^{312}$ Was it the failure to produce sufficient factual findings in Croson that made Justice O'Connor an epistemic skeptic? ${ }^{313}$ Was it the worry over racial self-dealing? ${ }^{314}$ Would she have been more deferential if whites instead of blacks held five of the nine seats on the city council $?^{315}$ Do we trust the claims of white citizens more than we trust those of citizens of color? ${ }^{316}$ One wonders if that is what Justice Thomas means when he stated in Grutter that the "majority grants deference to the Law School's 'assessment that diversity will, in fact, yield educational benefits.' It follows, therefore, that an [Historically Black College's] assessment that racial homogeneity will yield educational benefits would similarly be given deference."317

Why then are Justice Thomas's views in Black more credible than in other racial contexts? In other words, why might his fellow Justices find his views more worthy of belief in Black than in other cases?

The Court defers to Justice Thomas on factual and experiential questions dealing with race when the Court believes that he represents the views of citizens of color. Compare here Black and Grutter. Black turns almost exclusively upon a very specific, descriptive, racial, and experiential question: is cross burning invariably intimidating? This is a question about which Justice Thomas claims and ostensibly possesses superior knowledge; he is at an epistemic advantage. The nature of Justice Thomas's participation in this case is that of an insider (person of color) explaining to outsiders (white colleagues)

308. Croson, 488 U.S. at 477-78. "Minority Business Enterprise" is defined by the plan as "[c]itizens of the United States who are Blacks, Spanish-speaking, Orientals, Indians, Eskimos, or Aleuts." Id. at 478.

309. Id. at 479 .

310. Id. at 495 .

311. In Grutter the context was education and in Croson contracting.

312. In Croson, the Court intimated that it owed greater deference to congressional findings than to findings by state and local officials. Id. at 490 . But see Adarand Constructors, Inc., v. Pena, 515 U.S. 200 (1995).

313. See Croson, 488 U.S. at 500.

314. See id. at 493 (expressing concern with "simple racial politics").

315. See $i d$. at 495 (noting that "[f]ive of the nine seats of the city council are held by blacks."). What does this tell us anyway about Justice O'Connor's conception of race and representation? $C f$. Shaw v. Reno, 509 U.S. 630, 650 (1993) (O'Connor, J.) (maintaining that race-based districting "reinforces racial stereotypes and threatens to undermine our system of representative democracy by signaling to elected officials that they represent a particular racial group rather than their constituency as a whole").

316. See generally Cheryl I. Harris, Whiteness as Property, 106 HARv. L. REv. 1709 (1993).

317. 539 U.S. at 365. 
what cross-burning means from the perspective of an insider.

Moreover, when Justice Thomas speaks in Black, in a very important and poignant way, he speaks on behalf of victims or potential victims of cross burnings, who are disproportionately people of color. ${ }^{318}$ Perhaps more significantly, his views in Black are consistent with those of other elites of color. In Black, race is the salient characteristic, the primary explanatory variable. Justice Thomas's voice is not simply the voice of a conservative, but that of a black conservative and of a black nationalist. ${ }^{319}$ Not surprisingly, both ideologies, black conservatism and black nationalism, have deep historical roots within black political thought ${ }^{320}$ and permeate Justice Thomas's opinions. ${ }^{321}$ Thus, Justice Thomas's theory of the relationship between cross-burning statutes and the constitution reflects a widely shared viewpoint among black elites. Indeed, his approach to the constitutionality of cross-burning statutes in Black, especially the connection that he draws between white supremacy and cross burning, is fully consistent with the antisubordination principle as propounded by critical race theorists and legal academic elites of color. ${ }^{322}$

Justice Thomas's opinion in Grutter is similar to his opinion in Black in some respects. As in Black, in Grutter Justice Thomas attempts to explain the meaning of a racialized event from the perspective of an insider. He opens his dissent in Grutter with a quotation from Frederick Douglass's speech, "What the Black Man Wants." Douglass wrote:

[1]n regard to the colored people, there is always more that is benevolent, I perceive, than just, manifested towards us. What $I$, ask for the negro is not benevolence, not pity, not sympathy, but simply justice. The American people have always been anxious to know what whey shall do with us ... . I have

318. See Donald P. Green \& Andrew Rich, White Supremacist Activity and Crossburnings in North Carolina, 14 J. QuANT. CRIM. 263, 267 (reporting results of cross-burning incidents in North Carolina for 1987-1993).

319. Black nationalism is "based on the contention that understanding the plight of blacks and achieving black salvation must be based on taking race and racial oppression as the central feature of modern world history." Michael Dawson, Black Visions: The Roots of Contemporary AfricanAMERICAN Political IDEOLOGIES 86 (2001).

320. Id. at 19-23.

321. Mark Tushnet, Clarence Thomas's Black Nationalism, 47 How. L.J. 323 (2004).

322. Mari J. Matsuda et al., Words that Wound: Critical Race Theory, Assaultive Speech, and THE FIRST AMENDMENT 15, 136 (1993) (arguing that the First Amendment reflects an antisubordination principle); Ruth Colker, Anti-Subordination Above All: Sex, Race, and Equal Protection, 61 N.Y.U. L. REV. 1003, 1007-08 (1986) (explaining that the antisubordination principle "seeks to eliminate the power disparities between men and women, and between whites and non-whites, through the development of laws and policies that directly redress those disparities. From an anti-subordination perspective, both facially differentiating and facially neutral policies are invidious only if they perpetuate racial or sexual hierarchy."). 
had but one answer from the beginning. Do nothing with us! Your doing with us has already played mischief with us. Do nothing with us! $!^{323}$

"What the Black Man Wants," Justice Thomas explains (to his white audience?), is to be left alone from the patronizing meddling of well-meaning white social engineers. ${ }^{324}$ Moreover, the "benighted notions"325 that underlie affirmative action programs are harmful to its supposed beneficiaries. "The Law School tantalizes unprepared students with the promise of a University of Michigan degree and all of the opportunities that it offers. These overmatched students take the bait, only to find that they cannot succeed in the cauldron of competition.",326

Perhaps more importantly, affirmative action stigmatizes both low-achieving and high-achieving African-Americans. Affirmative action programs are harmful to persons of color because they "stamp minorities with a badge of inferiority and may cause them to develop dependencies or to adopt an attitude that they are 'entitled' to preferences." 327 The programs also stigmatize highachieving persons of color because whites assume that all persons of color, regardless of their merit, are beneficiaries of affirmative action:

The majority of blacks are admitted to the Law School because of discrimination, and because of this policy all are tarred as undeserving. ... When blacks take positions in the highest places of government, industry, or academia, it is an open question today whether their skin color played a part in their advancement. The question itself is the stigma-because either racial discrimination did play a role, in which case the person may be deemed "otherwise unqualified," or it did not, in which case asking the question itself unfairly marks those blacks who would succeed without discrimination. ${ }^{328}$

These objections to the majority's decision in Grutter are very similar to

323. 539 U.S. at 349 (quoting Frederick Douglass, What the Black Man Wants, Address delivered in Boston, Massachusetts (Jan. 26, 1865), in 4 The Frederick Douglass Papers 59, 68 (John W. Blassingame \& John R. McKivigan eds., 1991)).

324. Id. at 350 ("Like Douglass, I believe that blacks can achieve in every avenue of American life without the meddling of university administrators.").

325. Id. at 371 .

326. Id. at 372 .

327. Id. (quoting Adarand Constructors, Inc. v. Pena, 515 U.S. 200, 241 (1995) (Thomas, J., concurring in part and concurring in judgment)).

328. Id. at 373 . This is an interesting point. Justice Thomas's argument is essentially that affirmative action restricts the liberty of those African-Americans who are not its beneficiaries and diminishes the value of their accomplishments. These individuals do not have the option of exit. No matter what they do, they are equally tarred. The point is made eloquently by Professor Marcus Cole, an AfricanAmerican law professor at Stanford Law School. See Marcus Cole, Eugene Misses the True Racism, the Point, and an Opportunity (An Open Letter) (on file with author). Professor Cole maintains that "many of those on the left" subscribe to the "arrogant and utterly racist mind-set" that "successful AfricanAmericans owe their success to Affirmative Action as the but-for cause of their success." Professor Cole goes on to note: 
those that Justice Thomas advanced in Black. Justice Thomas's objections are based upon his personal experiences as a person of color. As in Black, he speaks from an insider's perspective. ${ }^{329}$ In particular, when Justice Thomas maintains that whites assume that high-achieving African-Americans attain their positions only because of race and that this assumption stigmatizes and diminishes the accomplishments of African-Americans, he is drawing from his own personal experiences. ${ }^{330}$ However, in Black, his objections had a wider impact on his colleagues, in Grutter, less so, if at all. Why is that so?

An important difference between Justice Thomas's opinion in Black and his opinion in Grutter is the fact that Justice Thomas's views in Grutter are not representative of the views of elites of color. In Grutter, Justice Thomas speaks solely from the perspective of a black conservative. ${ }^{331}$ 'This perspective is

In the current Affirmative Action environment ... there is nothing that any American of African descent can do that can separate himself or herself from the unspoken accusation that he or she is the beneficiary of more than they deserve.

Let me illustrate the point. I am willing to bet that I am the only member of this list who feels compelled to put his standardized test scores and National Merit award on his CV. Why do I do this? For those of you who do not know me personally, it is not a matter of braggadocio. Every September I have to deal with nearly 60 prima donna first year law students whose first and only (initial) reaction to my skin color is that they have been cheated out of a "real" Contracts professor, and are stuck with an "Affirmative Action" instructor. Many of them come around when, as some "gunners" often do, they look up my CV and find that I have outscored virtually every single one of them on the test around which they have centered their lives, the LSAT. Others usually come around by mid semester when they have had an opportunity to compare my teaching to that of their other instructors. If numbers (standardized test scores and teaching evaluations) could obscure my skin color, my life would be heavenly.

....

I recently told a "pro-affirmative action" friend who teaches at the University of Pennsylvania that my dream for my two sons is different than most other Americans. While most other Americans dream of sending their children off to Harvard, Yale or Stanford, I dream of my two sons attending the University of California at Berkeley, a school to which only the objective accouterments of their abilities will gain them access. I am very pessimistic that this society will ever see past their skin color to actually value and enjoy them for the talents with which God endowed them, and the character with which I hope to leave them. Instead, I fear that they, like me, will engage in a year-in, year-out, day-in, day-out, relentless pursuit of personal liberty, and the respect necessary to exercise it.

329. Essentially, Justice Thomas is saying, "You white folks think you're doing us a favor, but you're not. Your concern is driven by white guilt. You're patronizing us, you're not doing anything to help those of us who really need help, and you're treating those of us who do not need help as second-class citizens."

330. As one commentator remarked, "[o]ne would have to have a completely tin ear not to hear the reference to high places in government as identifying Justice Thomas himself." Tushnet, supra note 321 , at 338 .

331. See, Tushnet, supra note 321, at 330-31. As Professor Tushnet has remarked, Justice Thomas's nationalism is at odds with his black conservatism. "Nationalism, though, is precisely the kind of group identity that Justice Thomas's individualism rejects." Id. One way of reconciling these two positions is to engage the separatist strand of black nationalism. Black nationalism sometimes encompasses separatism with a focus on self-help and self-empowerment. DAwson, supra note 319, at 129-30. As Dawson explains, "black conservatives are more likely to find allies among black nationalists who 
deeply individualistic. As Professor Dawson has noted:

Key ideological traits [of black conservativism] include reliance on self-help, an attack on the state as a set of institutions that retard societal progress in general and black progress in particular, and belief in the antidiscriminatory aspects of markets, all in the name of service to the black community.... Further, any strategy or policy which diminishes the "honor" of African Americans by allowing one to hold the perception that blacks are receiving an underserved benefit is considered both immoral and counterproductive. Finally, claims that blacks have suffered special oppression and deserve special consideration are rejected for a number of reasons, including the view that blacks are one of several groups that have suffered disadvantage and therefore should receive no special consideration. ${ }^{332}$

As scholars have demonstrated, black conservatism is not representative of the views of most African-Americans. ${ }^{333}$ In fact, as between black nationalism and black conservatism, black nationalism holds a much greater sway over the imagination of most African-Americans than does black conservatism. ${ }^{334}$ If Justice Thomas's claim to epistemic authority is based upon the insight he provides into the impact of the Court's decision on communities of color, it is not implausible to believe that Justice Thomas's epistemic authority would ebb and flow depending upon whether his views are likely to be those of the people for whom he speaks. Black and Grutter suggest that Justice Thomas's epistemic authority is context-dependent. His credibility depends, at least in part, upon whether his views are regarded as representative of the views of citizens of color. When Justice Thomas represents the views of a majority of citizens of color, as in Black, his epistemic authority is determinative. When his views are those of a distinct numerical minority, he commands less epistemic deference. ${ }^{335}$

resolutely reject the West and its ideological products than among adherents of other ideologies who share a common enlightenment heritage with black conservatives." Id. at 282.

332. Dawson, supra note 319, at 19-20.

333. See, e.g., id. at 281. ("Black conservatives are the most visible black ideologues in mainstream (white) American media and cultural outlets, but they have little mass support. Not only are their major policy positions on race and economics rejected, black conservative candidates are routinely shunned at
the polls.").

334. DAwson, supra note 319 , at 83 . Dawson's findings on this issue are quite remarkable. He notes very strong support among African-Americans for black nationalism and extremely weak support for, indeed strong opposition to, black conservatism. Id.

335. One cannot help but note the irony here. While Justice Thomas decries the use of race as a basis for credibility and maintains that racial considerations in the division of societal goods are inconsistent with merit-based evaluation, he does use race and racial iconography to enhance the legitimacy of his claims and to leverage his credibility. Adrienne D. Davis \& Stephanie M. Wildman, The Legacy of Doubt: Treatment of Sex and Race in the Hill-Thomas Hearings, 65 S. CAL. L. REv. 1367, 1391 (1992) (noting that at his confirmation hearings "Justice Thomas played the race card, a card he had proclaimed was not in his deck."); see also DAwson, supra note 319, at 281-82; Tushnet, supra note 321 , passim. 
This epistemic account of Justice Thomas's role in Black raises a number of interesting issues. First, how are we to understand the limitations of Justice Thomas's epistemic authority? Put differently, is the Court deferring to Justice Thomas or is the Court deferring to elites of color? Relatedly, if it is true that the Court defers to Justice Thomas when the Court perceives that his views coincide with those of elites of color, would the same data that allow us to reach this conclusion render Justice Thomas's own views superfluous? What matters is Justice Thomas's ability to claim epistemic authority. When Justice Thomas speaks on behalf of a united community of color, his claim to epistemic authority is strengthened. ${ }^{336}$

Further, the difference between Justice Thomas and elites of color is that Justice Thomas's position on the Court makes it difficult for his colleagues to ignore his claim to epistemic authority. Moreover, the costs of not deferring to Justice Thomas are greater when his views are representative of elites of color. That is, his fellow Justices would have to contradict Justice Thomas's account, which would be difficult to do, or would have to contemptuously ignore him.

One can provide a cynical as well as a less-cynical account of the limitations to Justice Thomas's epistemic authority. Cynically, one could argue that Justice Thomas serves as a convenient pass-through for white conservative ideologues. Thus, when President George H.W. Bush nominated then-Judge Thomas to the Court, many court-watchers concluded that the President was using Judge Thomas to advance a conservative agenda. ${ }^{337}$ Similarly, some commentators have accused Justice Thomas of being subservient to the intellectual agenda of Justice Scalia. $^{338}$

This point is not limited to Justice Thomas. Many commentators discredit

336. Compare the actualities of the case and the Court's decision with two hypothetical scenarios. Assume in both hypotheticals that the Court's ideological predisposition remains constant. In the first, an all-white Supreme Court considers and decides Black. Assume in this hypothetical that AfricanAmerican elites overwhelmingly would prefer a reversal of the Virginia Supreme Court. In the second hypothetical the current Court considers and decides Black but African-American elites are divided on meaning of cross burning. A minority shares Justice Thomas's views but a majority considers cross burning hate speech that is annoying but not seriously intimidating. When the African-American community is divided, Justice Thomas's claim on the meaning of a racialized event is empirically undermined. Thus, his claim to epistemic authority is correspondingly weakened.

337. See generally John O. Calmore, Airing Dirty Laundry: Disputes Among Privileged BlacksFrom Clarence Thomas to "The Law School Five," 46 How. L.J. 175 (2003); see also Richard L. Berke, Judge Thomas Faces Bruising Battle With Liberals Over Stand on Rights, N.Y. TIMEs, July 4, 1991, at A12; Maureen Dowd, Conservative Black Judge, Clarence Thomas, Is Named to Marshall's Court Seat, N.Y. Tmes, July 2, 1991, at A1; Steven A. Holmes, N.A.A.C.P. and Top Labor Unite to Oppose Thomas, N.Y. TIMEs, Aug. 1, 1991, at A1; Ruth Marcus, Thomas's Conservatism Displayed in Speeches, Writings, Wash. Post, July 3, 1991, at A15; E.R. Shipp, Feminists Oppose Nominee To Court, N.Y. TIMEs, July 6, 1991, at A7.

338. E.g. Calmore, supra note 337, at 180-81 ('In 1996, Emerge ('Black America's Newsmagazine') placed Justice Thomas on its cover in caricature as a lawn jockey standing outside of the 'Supreme Court. Within the magazine, there was a depiction of the Justice shining the shoes of Justice Scalia."); see also Laura A. Ingraham \& Stephen F. Smith, The War Against Clarence Thomas, WASH. Post, Nov. 6, 1994, at C2 (describing frequent criticism that Justice Thomas is simply a "clone" of Justice Scalia). 
conservatives of color, in particular black conservatives, by arguing that conservatives of color are stooges for white conservatives. ${ }^{339}$ These arguments deny agency to conservatives of color, and often reek of racism, even when they are being advanced by left-of-center commentators of color. In any event, whether or not these types of arguments have any merit in other contexts, they are certainly not applicable to Justice Thomas in Black. ${ }^{340}$

Less cynically, Justice Thomas's ability to persuade might be limited to Justices who share, more or less, his ideological predispositions. ${ }^{341}$ If so, it is not surprising that Justice Thomas's participation in Black affected the Court's most conservative Justices. In particular, Justice Thomas appeared to have the most effect on Justice Scalia.

One must wonder, if one were to substitute Justice Marshall for Justice Thomas, whether Justice Marshall would have had the same effect. Professor Tushnet provides evidence that Justice Marshall did not have a similar effect on other Justices. ${ }^{342}$ Even though Justice Marshall attempted to use his epistemic authority during his tenure on the Court in the same manner as Justice Thomas did in Black, ${ }^{343}$ Professor Tushnet notes that Justice Marshall was not extremely successful. ${ }^{34}$ For the majority of Justice Marshall's time on the Court, he was one of the most liberal members on a Court that became increasingly conservative. ${ }^{345}$ Thus, while many members of the Court testified, as did Justice White, that Justice Marshall "would tell us things that we knew but would rather forget; and he told us much that we did not know due to the limitations of our

339. Take a recent speech by NAACP president Kweisi Mfume to that organization at its annual convention. Mr. Mfume stated, "When the ultraconservative right-wing attacker has run out of attack strategy, he goes and gets someone that looks like you and me to continue the attacks .... And like the ventriloquists' dummies, they sit there in the puppet master's voice, but we can see whose lips are moving, and we can hear his money talk." Steve Miller, Mfume Calls Black Conservatives Puppets, WASH. TMES, July 13, 2004, at A3, available at $\mathrm{http} / / / \mathrm{ww}$ w.washtimes.com/national/20040712-1038484561r.htm. In return, a prominent black conservative continued to add to the elevated intellectual tenor of this debate by accusing the NAACP of being a stooge organization for "liberal white organizations." Id.; see also Calmore, supra note 337, at 207-08; Christopher Hitchens, Minority Report, NATion, Nov. 4, 1991, at 542; Barbara Ransby and Cheryl I. Harris, Uncle Tom's Cabinet? A Few Black Faces at the Top Won't Quell the Outrage at the Bottom, IN THESE Times, Jan. 22, 2001, at 16; James Strong, Black Conservationism: 12 Years Of Failure, New PITT. CourIER, Mar. 3, 1993, at A6.

340. Two observations support this conclusion. First, Justice Thomas wrote a separate dissent when he could have joined in the majority opinion or simply joined in Justice Scalia's opinion. Second, Justice Thomas would have decided this case differently than the other eight Justices. His framework is significantly broader than the majority's and that articulated by Justice Scalia. For example, he would have upheld the conviction of Barry Black, the Ku Klux Klan leader, which no one else would have upheld. See Virginia v. Black, 538 U.S. 343, 400 (2003) (Thomas, J., dissenting).

341. I am grateful to Mark Tushnet for helping me to understand this point.

342. Mark V. Tushnet, Making Constitutional LaW: Thurgood Marshall and the Supreme Court 1961-1991, at 57 (1997).

343. Id. at 5 ("Marshall saw his role as educating not only the public but his judicial colleagues as well, because their experiences were more limited than his."); see also id. at 7 ("Marshall was particularly alert in reminding his colleagues about issues of race.").

344. Id. at 57,67 .

345. Id. at 57 . 
experience,"346 the "conservative Court on which he served listened and then pretty much went on with its business." 347

In contrast, as Professor Tushnet explains, Justice Marshall was influential in the early years of his tenure on the Court, which coincided with the heyday of the Warren Court. In particular, Professor Tushnet explains how the Court came to adopt a doctrinal approach suggested by Justice Marshall, which eventually became the Court's decision in Roe v. Wade. ${ }^{348}$ Justice Marshall also experienced some important wins in the latter stages of his career. "Marshall's role in prodding the Court to pay attention to the constitutional law regarding race culminated in his successful campaign to overturn Swain v. Alabama,"349 a decision in which the Court had concluded that race-based peremptory challenges did not violate the Fourteenth Amendment. ${ }^{350}$ In Batson v. Kentucky, ${ }^{351}$ the Court overturned Swain. Though Justice Marshall did not succeed in getting the Court to adopt his more expansive framework-recall Justice Thomas in Black - he was responsible for the outcome. ${ }^{352}$

Thus, while the epistemic authority account has its limitations, it is important that students of the Supreme Court come to terms with the concept's impact on the process of judicial decision-making. ${ }^{353}$

Second, the epistemic account casts doubt upon claims, often made on the left, that Justice Thomas's jurisprudence is racially insensitive. As this Article illustrates, Justice Thomas's jurisprudence is deeply preoccupied with the relationship between law and race. In fact, if critical race theorists are defined as those who are concerned with the manner in which "a regime of white supremacy and its subordination of people of color have been created and maintained in America" ${ }^{354}$ and who have a desire to change the existing power

346. Id. at 5 (quoting Justice White).

347. Id. at 67.

348. Id. at 6-7.

349. Id. at 64 .

350. See Swain v. Alabama, 380 U.S. 202 (1965).

351. 476 U.S. 79 (1986).

352. TushNET, supra note 342 , at 65-67.

353. An interesting question here is whether the interpretations of Holocaust survivors of the meaning of Nazi regalia ought to be given epistemic deference in the same way that we might grant epistemic deference to the interpretations of cross burning by African Americans. See, e.g., Collin v. Smith, 578 F.2d 1197 (7th Cir. 1978). I think the analysis will be similar to the analysis in Black. As with African Americans and cross burning, the epistemic claims of Holocaust survivors ought to be given deference and should be accommodated. The accommodation would be similar to the Court's accommodation in Black. Nazis ought to be permitted to march in full regalia in a town's main street or square. But they should not be permitted to, for example, target a street in which a large number of Holocaust survivors reside for such a parade. In other words, Nazis ought to have the same access to the public square as cross burners. But beyond that, they should not be permitted to specifically target their messages of intimidation to the groups who would most clearly understand the message and would be most clearly intimidated.

354. Critical Race Theory: The Key Writings that Formed the Movement xiii (Crenshaw et al., eds., 1995). 
relationship between law and race, Justice Thomas is a critical race theorist. ${ }^{355}$ In other words, if critical race theory is the "creat[ion] of oppositionist accounts of race," Justice Thomas's dissent in Black and his participation in the case is critical race theory. Granted, it is not critical race theory in its orthodox form, and it is certainly conservative, but in Black it is critical race theory.

This observation raises the possibility that progressive scholars of color, in particular, may have neglected to observe areas of commonality with a justice who has been universally vilified by the academic left. It is possible, in certain issues involving race, that Justice Thomas and left-of-center scholars of color may find common ground if they look for it. It is also possible-concededly not probable, but nevertheless possible- that if Justice Thomas is engaged by what he calls "constructive" and "scholarly criticism," 356 scholars of color might succeed in influencing his opinion on issues of mutual concern. Indeed, if one takes Justice Thomas at his words- that he finds "thoughtful, analytical criticism most helpful" from "outside scholarship" as opposed to "personalize[d]," "bilious and venomous assaults"357 - he would be open to such engagement. For example, both Justice Thomas and progressive scholars of color have expressed frustration with the manner in which the public education system has failed African-American children. Some progressive scholars of color, such as Derrick Bell, have argued that the judicial emphasis on integration spawned by Brown v. Board of Education is one source of this failure. ${ }^{358}$ One wonders whether they could construct a mutually acceptable jurisprudence to address if not resolve this problem.

Third, my account of Justice Thomas's participation in this case also casts doubts on the agenda of conservatives of color who would deny the useful power of race-consciousness and the manner in which a focus on raceconsciousness advances the goal of racial justice. ${ }^{359}$ Ironically, Justice Thomas's epistemic authority derives from his race and his racial experiences. ${ }^{360}$ Justice Thomas's questions during oral argument in Black were a brilliant use of epistemic authority based upon race. ${ }^{361}$ Without actually saying so, he chal-

355. Id.

356. Justice Clarence Thomas, Speech to the National Bar Association (July 28, 1998) (transcript available at http://teachingamericanhistory.org/library/index.asp?documentprint=507) (on file with author).

357. Id.

358. See Derrick Bell, Silent Covenants: Brown v. Board of Education and the Unfulfilled Hopes for Racial Reform 160-179 (2004); see also Girardeau A. Spann, Race Against the Court: The Supreme Court and Minorities in Contemporary America 113-16 (1993).

359. See, e.g., Shelby Steele, The Content of our Character: A New Vision of Race in America (1990).

360. Recall here Justice Thomas's famous statement in his speech to the National Bar Association, supra note 356: "I am a man, a black man, an American. And my history is not unlike that of many blacks from the deep South. And in many ways it is not that much different from that of many other Americans."

361. For similar examples of epistemic authority based upon racial experiences by Justice Thurgood Marshall, see TuSHNET, supra note 342, at 8. 
lenged the epistemic account of all parties involved-his colleagues as well as the attorneys-on the meaning of cross-burning. After all, who is going to question the Court's lone Black member, and a conservative no less, on the meaning of cross-burning? Moreover, how would one go about refuting Justice Thomas's epistemic account?

Thus far, we have ignored a broader and perhaps more difficult question: what role ought personal or even professional experience play in the adjudicative process? Ought we defer to Justices O'Connor and Ginsburg on gender issues? Ought we defer to Justice Breyer on issues involving administrative law or Justice Ginsburg on civil procedure because of their acknowledged expertise in those areas? Should the Court ever defer to the epistemic authority of one of its members, especially when that authority is based upon personal experience? These are indeed complicated issues.

On one view, we have an epistemic account of adjudication that is incompatible with epistemic deference granted on the basis of a judge's personal and professional experiences. We have an adversary system where parties are responsible for presenting their sides of the issues and getting their sides on the record. We have a trier of fact, whose responsibility is to find the facts. We also defer to the trier of fact. Thus, every first-year law student knows that in the federal courts the reviewing court must affirm a jury's decision unless there is no legally sufficient evidentiary basis for a reasonable jury to find as the jury found; and that a judge's finding of fact is reviewed for clear error. Our epistemic account of adjudication indicates that judges ought to decide cases on the basis of the facts as they are on the record and on the basis of "the law."

However, notice how much this epistemic account of adjudication sounds like the now disfavored sociological jurisprudence of old. But if we learned anything at all from legal realism, critical legal studies, critical race theory, and feminist critical theory, it is that concepts such as "law" and "fact" are highly contested, unstable, political, and indeterminate.

One need not be a crit to recognize that personal testimonies, while they cannot be central to the adjudicative process, are useful at the margins. We have already encountered Justice O'Connor's tribute to the importance and impact to his colleagues of Justice Marshall's "special perspective." Justice Powell also stated that "a member of a previously excluded group can bring insights to the Court that the rest of its members lack." ${ }^{362}$ At least one commentator has noted that the "participation of women and minorities on the bench may add a dimension of justice to the courts." 363

Thus, on another view, some questions of constitutional law cannot be understood and justly resolved apart from personal experience. Determining

362. Barbara A. Perry, A "Representative" Supreme Court? The Impact of Race, Religion, and GENDER ON APPOINTMENTS 137 (1991).

363. Sheldon Goldman, Federal Judicial Recruitment, in ThE American Courts: A CrItical AssessMENT 189, 205 (John B. Gates \& Charles A. Johnson eds., 1991). 
whether having a cross burned on one's yard is threatening requires either personal experience or the willingness to defer to someone else's epistemic account.

In any case, Justice Thomas's role in Black is difficult to ignore. Whether one approves of it at least depends upon whether one believes that Black is a better case-better, for example, than R.A.V.-because of Justice Thomas's active participation.

\section{THE TRIUMPH OF THE CRITS?}

While Black is notable for its outcome, its doctrinal divergence from R.A.V., and the role that Justice Thomas played in the case, it is equally remarkable as a judicial exercise in critical race theory. From the perspective of critical race theory, Virginia v. Black is significant in a number of respects, three of which are worth addressing here. Critical race theorists have argued that cross-burning legislation, and hate speech legislation more generally, should be understood within the historical context from which they arise. ${ }^{364}$ Second, they have argued that the Court should use the historical context to frame its doctrinal analysis. ${ }^{365}$ Lastly, they have argued that First Amendment doctrine is sufficiently capacious to protect speech and accommodate legislation targeting cross burnings. ${ }^{366}$ Each of those perspectives is reflected in the majority opinion in Black.

First, as critical race theorists suggested, the Court used history to define, contextualize, and cabin the constitutional harm. Justice O'Connor's analysis begins with an overview of the history of cross burning in the United States. This historical overview provides five lessons. First, cross burning in the United States is uniquely associated with the Ku Klux Klan. ${ }^{367}$ Second, cross burning is a harbinger of impending violence and is usually followed by violence. ${ }^{368}$ Third, a critical purpose of cross burning is intimidation. ${ }^{369}$ Fourth, cross burning need not be followed by violence to be intimidating; the burning cross itself draws upon the historical well of past violence and suffices as an impor-

364. Thus, Mari Matsuda and Charles Lawrence, for example, wrote approvingly of the Minnesota Supreme Court's original decision, subsequently overturned in R.A.V., to uphold St. Paul's crossburning statute: "The Minnesota judges . . . adopted a perspective urged by critical race theorists. They looked to the history and context to understand the effect of cross burning." Matsuda \& Lawrence, supra note 214 , at 134 .

365. Id. at 135 ("Judges from Oliver Wendell Holmes to Harry Blackmun have not had to be radicals to recognize the simple truth that doing justice requires more than manipulating doctrine in a vacuum.").

366. See Matsuda, supra note 213, at 2356-62.

367. Virginia v. Black, 538 U.S. 343, 352 (2003) ("Burning a cross in the United States is inextricably intertwined with the history of the Ku Klux Klan.").

368. See id. at 354 ("C]ross burnings have been used to communicate both threats of violence and messages of shared ideology.").

369. See id. ("Often, the Klan used cross burnings as a tool of intimidation and a threat of impending violence."). 
tant warning of what may follow. ${ }^{370}$ Fifth, this history has contemporary significance. Modern-day cross burners continue to engage in the practice, in part, to intimidate others. ${ }^{371}$ Moreover, they are capable of intimidating their victims because of this collective shared history that continues to retain its salience. $^{372}$

The Court's historical overview culminated in the conclusion that "cross burning is often intimidating, intended to create a pervasive fear in victims that they are a target of violence." ${ }^{373}$ This conclusion on the historical and contemporary meaning of cross burning stands in sharp contrast to R.A.V. In R.A.V., Justice Scalia failed to explicitly discuss the harm caused by cross burnings. ${ }^{374}$ In fact, Justice Scalia reserved only a single sentence, toward the end of his opinion, in which he observed, "burning a cross in someone's front yard is reprehensible."375

Moreover, Justice Scalia in R.A.V. is inconsistent with Justice Scalia in Black. Contrast Justice Scalia's characterization of cross burning as "reprehensible" in R.A.V., with the following statement in an exchange with Dean Rodney Smolla, who represented the respondents in Black before the Supreme Court, during oral argument in the case:

[Dean] Smolla: If I see a burning cross, my stomach may churn. I may feel a sense of loathing, disgust, a vague sense of ... being intimidated.

Question: How about a cross-how about a cross -

[Dean] Smolla: But that's not fear of bodily harm.

Question: How about a cross on your lawn?

[Justice Scalia]: Yes. I dare say that you would rather see a man with a - with a rifle on your front lawn-If you were a black man at night, you'd rather see a man with a rifle than see a burning cross on your front lawn.

[Dean] Smolla: Your Honor, I concede that. ${ }^{376}$

Note that Dean Smolla's position-that a burning cross may make one's stomach churn or may induce feelings of loathing or disgust-is quite consistent with Justice Scalia's position in R.A.V. that a burning cross is reprehensible. But there is a vast difference between cross burning as a reprehensible act-

370. Id. at 355 ("[C]ross burnings embodied threats to people whom the Klan deemed antithetical to its goals. And these threats had special force given the long history of Klan violence.").

371. Id. at 357 .

372. In fact, one may argue that this history permits cross burners to intimidate with greater efficiency while at the same time reducing the cost of intimidation to themselves. Cross burners, whether they are associated with the Klan or not, may free ride on the history of cross burning in order to communicate a credible threat of violence without incurring greater costs in the form of punishment for bodily harm and actual violence. Thus, they can achieve virtually the same effect at lower cost or risk to themselves.

373. Id. at 360 .

374. See Matsuda \& Lawrence, supra note 214 , at 134-35.

375. R.A.V. v. City of St. Paul, 505 U.S. 377, 396 (1992).

376. Transcript, supra note 251 , at 30. 
presumably worthy of constitutional protection, Dean Smolla's point and Justice Scalia's position in R.A.V.-and cross burning as an act of imminent intimidation, an act of violence-presumably unworthy of constitutional protection and Justice Scalia's position in Black. ${ }^{377}$

Second, the Black majority used the historical overview to frame the ensuing doctrinal analysis. Threats and acts of intimidation are proscribable under the First Amendment. Cross burning committed with the intent to intimidate an individual or a group of persons is a type of threat. Consequently, cross burnings can be proscribed consistent with the First Amendment. The result of this doctrinal move is the revival of the true threat doctrine. Specifically, cross burnings are a type of true threat "where the speaker means to communicate a serious expression of an intent to commit an act of unlawful violence to a particular individual or group of individuals." 378 Once again, the Court's analysis stands in sharp contrast to R.A.V., which concluded, "St. Paul has sufficient means at its disposal to prevent [cross burnings] without adding the First Amendment to the fire."379

Third, the Court's analysis in Black supports the assertion of critical race theorists that current First Amendment doctrine is compatible with narrowly tailored cross-burning legislation. "The protections afforded by the First Amendment," Justice O'Connor stated in Black, "are not absolute." ${ }^{380}$ Victims of cross burning need not suffer such vile acts in the name of the First Amendment.

To truly appreciate the relationship between Black and critical race theory (and the nature of this relativist-non-absolutist-First Amendment), one must join the separate observations of two important theorists. The first observation is the contention of Professor Frederick Schauer that the

boundaries of the First Amendment, far more than the doctrine lying within those boundaries, turn out to be a function of a complex and seemingly serendipitous array of factors that cannot be (or at least have not been) reduced to or explained by legal doctrine or by the background philosophical ideas and ideals of the First Amendment. ${ }^{381}$

As he has explained, "the boundary between the speech that implicates the First Amendment and the speech that does not is as much a matter of history, sociology, culture, and politics, as it is a matter of formal constitutional doctrine

377. I cannot help but note that I do not know whether other black men (or black women) would rather see a (presumably white) man on their lawn at night with a rifle than a burning cross. But I do know that while this black man would prefer neither, if I must choose, I would take the burning cross. To the extent that the burning cross is a harbinger of things to come, the rifle is the real event.

378. See Black, 538 U.S. at 359.

379. R.A.V., 505 U.S. at 396.

380. Black, 538 U.S. at 358.

381. Frederick Schauer, The Boundaries of the First Amendment: A Preliminary Exploration of Constitutional Salience, 117 HARv. L. Rev. 1765, 1768 (2004). 
or philosophical free speech theory." ${ }^{382}$ From this observation Professor Schauer concluded that it may also be the case that "less of the First Amendment can be explained by the tools of legal analysis than we have formerly recognized."383

For the second observation we turn to Professor Don Herzog. Professor Herzog argues that controversies over epistemic authority are deeply political. ${ }^{384}$ Politics, he maintains, is the "realm of controversy over legitimate authority." 385 These are not controversies that can be solved by appeal to "reason" because such appeal is itself political. ${ }^{386}$ In other words, what counts as a valid reason is a contested contextual dispute.

When one combines the insights of Professors Schauer and Herzog, one is better able to appreciate the complex manner in which critical race theory interacts with Black. At bottom, critical race theory is a political claim about law and legal authority. For critical race theorists, appeals to legal authority are political. That is, these appeals cannot be understood as objective, reasonable appeals to logic or legal doctrine. They are sociological, cultural, political, economic, and racial. That they are so does not make them any less legitimatelegitimacy arguments are context-specific-but simply help us better understand areas of contestation and the nature of our disputes.

Disputes over legal authority tell us about who matters in our society. ${ }^{387}$ They tell us about whose injury counts as harm. ${ }^{388}$ Legal doctrine, in this case the First Amendment, is part of the rhetoric. ${ }^{389}$ Doctrine masks these disputes and cloaks their political resolution.

What critical race theory and epistemic authority help explain is how the First Amendment, which formerly could not countenance cross-burning statutes, has become less absolute in its scope. ${ }^{390}$ Seen from the lens of critical race theory, Black represents at least a partial triumph. ${ }^{391}$ Whereas R.A.V. appears to be a complete repudiation of the approach to hate speech advocated by the crits,

382. Schauer, supra note 161, at 348.

383. Schauer, supra note 381 , at 1768.

384. HERZOG, supra note 259 , at $155-60$.

385. Herzog, supra note 260 , at 465 .

386. HERZOG, supra note 259, at 156 ("For reason is itself the name of a series of political disputes.").

387. See Virginia v. Black, 536 U.S. 343, 398 (2003) (Thomas, J., dissenting) (accusing the plurality of caring more about the "innocent cross-burner" than the victims of cross burnings).

388. Consider in this vein Justice Thomas's brilliant move in Black where he asks why abortion protesters did not have a First Amendment right to harass individuals entering abortion clinics but cross burners had a First Amendment right to intimidate their victims. Id. at 399-400.

389. See Schauer, supra note 381, at 1794 (stating that "the First Amendment's magnetism leads strategic actors to embrace it as easily as politicians embrace motherhood, the flag, and apple pie").

390. Though Professor Schauer's arguments are limited to the scope of the First Amendment and not to its contents, see Schauer, supra note 381, at 1769-74, and though legal doctrine explains a great deal of the First Amendment's content, understanding the political nature of legal disputes in cases such as Black helps us to explain cases that are otherwise hard on the basis of legal doctrine alone.

391. The triumph is partial if only because in Black the Court is careful to protect the First Amendment rights of the white supremacist. The white supremacist goes free while the ostensibly non-racist troublemakers may still be convicted. 
Black seems to embrace it, at least in part. Black is a vindication of the critical race theorists and of critical race theory. ${ }^{392}$ The Black majority utilizes the tools of analysis recommended by critical race theorists to understand the harm caused by cross burnings and to determine how First Amendment doctrine should respond to cross burnings.

\section{CONCLUSION}

Black is best understood as representing a fundamental doctrinal shift with respect to cross burning. As I have argued in this Article, in R.A.V. the Court demonstrated a marked insouciance about the harm caused by cross burning and the state's effort to address that harm. Black is a much more nuanced approach to understanding the relationship between cross burning and free expression. Whereas R.A.V. erected an absolute prohibition on statutes singling out cross burnings for regulation, Black attempted to accommodate the state's effort to protect its citizens from the true threat posed by certain types of cross burnings. This distinctive type of racial violence is now relevant to the Court's doctrinal posture in First Amendment cases. Thus, Black represents a fundamental shift in the Court's doctrinal approach.

To best appreciate this shift, one must focus on Justice Thomas's unique participatory role in Black. As an African American, Justice Thomas displayed a remarkable sensitivity to the harm caused by cross burning. Justice Thomas's influence, demonstrating the power of epistemic authority and epistemic deference, has in turn provided the crits with an important victory.

392. But this triumph is ironic. It is the Court's conservatives who deliver this intellectual bounty. Indeed, the Justice who most approximately represents the critical race position on this issue is Justice Thomas, followed closely by none other than Justice Scalia. 


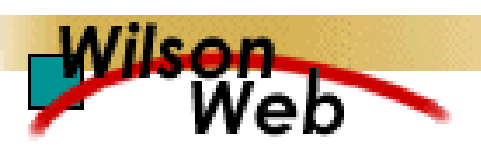

\section{COPYRIGHT INFORMATION}

TITLE: Colored Speech: Cross Burnings, Epistemics, and the Triumph of the Crits?

SOURCE: Georgetown Law J 93 no2 Ja 2005

WN: 0500103120004

The magazine publisher is the copyright holder of this article and it is reproduced with permission. Further reproduction of this article in violation of the copyright is prohibited. To contact the publisher: http://www.law.georgetown.edu/

Copyright 1982-2005 The H.W. Wilson Company. All rights reserved. 